\title{
Description and phylogenetic analysis of the Calycopidina (Lepidoptera, Lycaenidae, Theclinae, Eumaeini): a subtribe of detritivores
}

\author{
Marcelo Duarte ${ }^{1} \&$ Robert K. Robbins ${ }^{2}$
}

1'Museu de Zoologia, Universidade de São Paulo, Avenida Nazaré 481, Ipiranga, 04263-000 São Paulo, SP, Brazil. mduartes@usp.br
${ }^{2}$ National Museum of Natural History, Smithsonian Institution, P. O. Box 37012, NHB Stop 105, Washington, DC 20013-7012 USA. robbinsr@si.edu

\begin{abstract}
Description and phylogenetic analysis of the Calycopidina (Lepidoptera, Lycaenidae, Theclinae, Eumaeini): a subtribe of detritivores. The purpose of this paper is to establish a phylogenetic basis for a new Eumaeini subtribe that includes those lycaenid genera in which detritivory has been recorded. Morphological characters were coded for 82 species of the previously proposed "Lamprospilus Section" of the Eumaeini (19 of these had coding identical to another species), and a phylogenetic analysis was performed using the 63 distinct ingroup terminal taxa and six outgroups belonging to four genera. Taxonomic results include the description in the Eumaeini of Calycopidina Duarte \& Robbins new subtribe (type genus Calycopis Scudder, 1876), which contains Lamprospilus Geyer, Badecla Duarte \& Robbins new genus (type species Thecla badaca Hewitson), Arzecla Duarte \& Robbins new genus (type species Thecla arza Hewitson), Arumecla Robbins \& Duarte, Camissecla Robbins \& Duarte, Electrostrymon Clench, Rubroserrata K. Johnson \& Kroenlein revalidated status, Ziegleria K. Johnson, Kisutam K. Johnson \& Kroenlein revalidated status, and Calycopis. Previous "infratribe" names Angulopina K. Johnson \& Kroenlein, 1993, and Calycopina K. Johnson \& Kroenlein, 1993, are nomenclaturally unavailable and polyphyletic as proposed. New combinations include Badecla badaca (Hewitson), Badecla picentia (Hewitson), Badecla quadramacula (Austin \& K. Johnson), Badecla lanckena (Schaus), Badecla argentinensis (K. Johnson \& Kroenlein), Badecla clarissa (Draudt), Arzecla arza (Hewitson), Arzecla tarpa (Godman \& Salvin), Arzecla canacha (Hewitson), Arzecla calatia (Hewitson), Arzecla tucumanensis (K. Johnson \& Kroenlein), Arzecla sethon (Godman \& Salvin), Arzecla nubilum (H. H. Druce), Arzecla paralus (Godman \& Salvin), Arzecla taminella (Schaus), Arzecla albolineata (Lathy), Electrostrymon denarius (Butler \& H.Druce), Electrostrymon guzanta (Schaus), Electrostrymon perisus (H. H. Druce), Rubroserrata mathewi (Hewitson), Rubroserrata ecbatana (Hewitson), Kisutam micandriana (K. Johnson), and Kisutam syllis (Godman \& Salvin). The structure of the male genitalia lateral window, labides, and brush organs are described and discussed, as are the female genitalia signa of the corpus bursae and $8^{\text {th }}$ abdominal tergum. Widespread wing pattern sexual dimorphism in the Calycopidina is noted and illustrated, and the presence of alternating dark and light bands on the ventral wings of both sexes is discussed. The evidence for detritivory in Lamprospilus, Badecla, Arzecla, Arumecla, Camissecla, Electrostrymon, Ziegleria, Kisutam, and Calycopis is summarized using the new classification.
\end{abstract}

KEYWORDS. Butterfly; distribution; implied weighting; neotropical region; taxonomy.

RESUMO. Descrição e análise filogenética de Calycopidina (Lepidoptera, Lycaenidae, Theclinae, Eumaeini): uma subtribo de detritívoros. O objetivo desse trabalho é estabelecer a base filogenética para uma nova subtribo de Eumaeini incluindo os gêneros com registros de detritivoria. Foram codificados caracteres morfológicos para as 82 espécies previamente arroladas na Seção Lamprospilus de Eumaeini (19 delas tiveram codificação idêntica a outras espécies); posteriormente foi conduzida uma análise filogenética incluindo 63 táxons terminais do grupo interno e seis grupos-externos pertencentes a quatro gêneros. Como resultados taxonômicos incluem-se a descrição de Calycopidina Duarte \& Robbins subtribo nova (gênero-tipo Calycopis Scudder, 1876) e o reconhecimento de Lamprospilus Geyer, Badecla Duarte \& Robbins gênero novo (espécie-tipo Thecla badaca Hewitson), Arzecla Duarte \& Robbins gênero novo (espécie-tipo Thecla arza Hewitson), Arumecla Robbins \& Duarte, Camissecla Robbins \& Duarte, Elecrostrymon Clench, Rubroserrata K. Johnson \& Kroenlein revalidado, Ziegleria K. Johnson, Kisutam K. Johnson \& Kroenlein revalidado e Calycopis. Nomenclaturalmente, Angulopina K. Johnson \& Kroenlein, 1993 e Calycopina K. Johnson \& Kroenlein, 1993 são consideradas inválidas e polifiléticas tal como foram propostas. Novas combinações incluem Badecla badaca (Hewitson), Badecla picentia (Hewitson), Badecla quadramacula (Austin \& K. Johnson), Badecla lanckena (Schaus), Badecla argentinensis (K. Johnson \& Kroenlein), Badecla clarissa (Draudt), Arzecla arza (Hewitson), Arzecla tarpa (Godman \& Salvin), Arzecla canacha (Hewitson), Arzecla calatia (Hewitson), Arzecla tucumanensis (K. Johnson \& Kroenlein), Arzecla sethon (Godman \& Salvin), Arzecla nubilum (H. H. Druce), Arzecla paralus (Godman \& Salvin), Arzecla taminella (Schaus), Arzecla albolineata (Lathy), Electrostrymon denarius (Butler \& H. Druce), Electrostrymon guzanta (Schaus), Electrostrymon perisus (H. H. Druce), Rubroserrata mathewi (Hewitson), Rubroserrata ecbatana (Hewitson), Kisutam micandriana (K. Johnson) e Kisutam syllis (Godman \& Salvin). Descreve-se e discute-se a fenda lateral, a porção caudal do tegume e os órgãos-escova da genitália masculina, assim como os signos da bolsa copuladora e o oitavo tergito abdominal das fêmeas. Ressalta-se e ilustra-se o dimorfismo sexual no padrão de coloração das asas amplamente distribuído em Calycopidina, como também se discute a presença de bandas escuras e claras alternadas na face ventral das asas de ambos os sexos. A evidência de detritivoria em Lamprospilus, Badecla, Arzecla, Arumecla, Camissecla, Electrostrymon, Ziegleria, Kisutam e Calycopis é resumidamente discutida com base na nova classificação.

PALAVRAS-CHAVE. Borboleta; distribuição; pesagem implícita; região neotropical; taxonomia.

Caterpillars of the vast majority of butterfly species (Papilionoidea) eat vascular plants (Ehrlich \& Raven 1965), with larvae in some groups eating arthropods (Cottrell 1984; Pierce 1995) or lichens-fungi-algae (Wagner et al. 2008).
In addition, caterpillars of eight species of New World Lycaenidae, Riodinidae, and Satyrinae (Nymphalidae) (Gifford \& Opler 1983; S. Johnson 1985; Murray 2001; Hall \& Harvey 2002; Duarte et al. 2005) eat detritus, which is an 

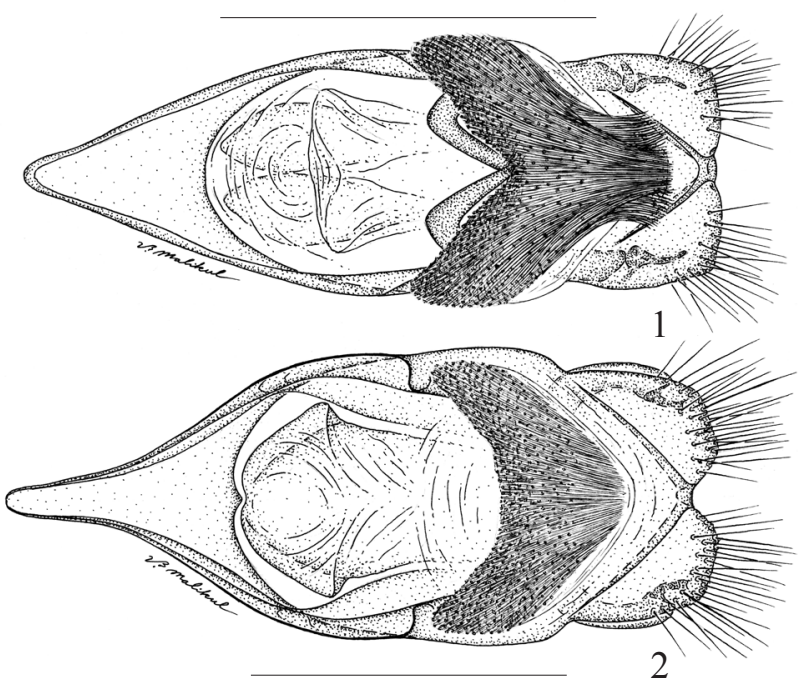

Figs. 1-2. Dorsal aspect of male genitalia brush organs, which are posteriorly fused, posterior of insect at right; 1, Strymon ziba (Honduras). 2, Lamprospilus coelicolor (Panama). Scale $1 \mathrm{~mm}$.

uncommon larval food in the Macrolepidoptera (Powell et al. 1998; Hohn \& Wagner 2002). Recent fieldwork indicates that facultative or obligate detritivory is more widespread in Lycaenidae than previously reported, occurring in several genera (Robbins et al. in prep.).

The lycaenid genera in which detritivory has been recorded were provisionally grouped in a checklist as the "Lamprospilus Section" of the Eumaeini (Lycaenidae: Theclinae) containing 120 described and 40 undescribed species (Robbins 2004b). Although parts of this section have been treated taxonomically (Field 1967a, b; K. Johnson 1988, 1990, 1991, 1993a, b, 1995; K. Johnson et al. 1988; K. Johnson \& Kroenlein 1993a, b, 1997; K. Johnson \& Sourakov 1993; Austin \& K. Johnson 1997; Canals \& K. Johnson 2000; K. Johnson et al. 2004; Robbins \& Duarte 2005), a phylogenetic overview of the entire group and its component genera is lacking.

The purpose of this paper is to establish and discuss the phylogenetic basis for the Calycopidina, a new subtribe equivalent to the Lamprospilus Section of Robbins (2004a), and for its included genera using adult morphology. The Calycopidina includes all lycaenid species in which detritivory has been recorded, and we briefly summarize the
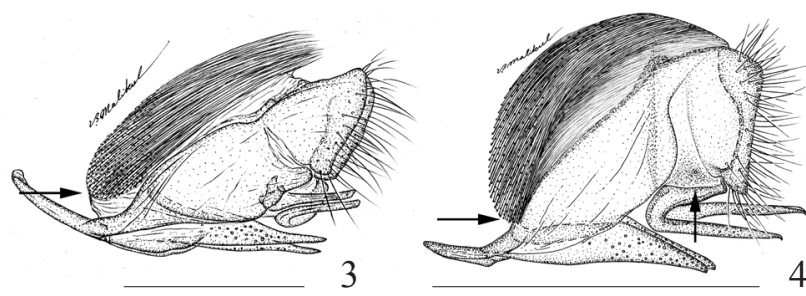

Figs. 3-4. Lateral aspect of male genitalia showing brush organs with the anterior end (arrow) on the ventral half of the genital capsule, posterior of insect at right; 3, Arzecla taminella (Peru); 4, Camissecla camissa (Ecuador) with base of gnathos longer than wide (arrow on right). Scale $1 \mathrm{~mm}$ evidence for facultative and obligate detritivory using the new generic classification.

\section{MATERIAL AND METHODS}

Characters were derived from a comparison of adult morphology using 11,000+ pinned Calycopidina specimens and about 1,400 genitalic dissections in the National Museum of Natural History (USNM), Smithsonian Institution, Washington, DC, USA, and Museu de Zoologia (MZSP), Universidade de São Paulo, SP, Brazil, plus numerous specimens borrowed from other museums and private collections (noted in acknowledgments). Characters were restricted to adult morphology because preserved immature stages are available for only seven Calycopidina species (Duarte et al. 2005; Duarte \& Robbins 2009) and DNA sequences are available for 13 (Quental et al. in prep.). For this study, we examined the male and female genitalia of each terminal taxon at least four times (twice by each co-author) as well as the genitalia of the vast majority of those Calycopidina that were not used as terminal taxa (selective criteria in next paragraph). An ocular grid was used to measure microscopic distances. Genitalic terms follow Klots (1970) except for a few additional terms referring to genitalic structures characteristic of the Lycaenidae or Eumaeini (Eliot 1973; Robbins 1991). Wing vein terminology follows Comstock (1918), and androconial terminology follows Robbins (1991). For other morphological structures, we follow Snodgrass (1935).

The 82 terminal ingroup taxa are those described Lamprospilus Section species for which both sexes, including their genitalia, were available for study (in the genus accounts; author and date of publication in Robbins 2004b; citations for virtually all original descriptions in Lamas et al. 1995). The terminal taxa include 21 of the 26 described Lamprospilus Geyer species listed in Robbins (2004b), all three described Arumecla Robbins \& Duarte, nine of 12 Camissecla Robbins \& Duarte, eight of nine Ziegleria K. Johnson, nine of ten Electrostrymon Clench, and 30 of 62 described Calycopis Scudder plus two subsequently described species (Robbins \& Duarte 2005). The females of some species with easily recognized males, such as Lamprospilus decorata (Lathy), are unknown or their identity is currently uncertain, for which reason they are omitted. We include only about half the recognized Calycopis species because the species level taxonomy of this genus is largely unresolved, especially the association of males and females (Robbins 2004a).

The outgroups for the phylogenetic analyses are six species of Strymon, Rekoa, Arawacus, and Thereus (cf. Robbins 1991, 2000; Robbins \& Nicolay 2002 for systematic treatments). These genera belong to the lineage that is the phylogenetic sister of the Calycopidina in maximum parsimony, likelihood, and Bayesian phylogenetic analyses of 3800+ DNA sequences for 163 Eumaeini (Quental et al. in prep.). Morphological evidence supports the choice of Strymon as an outgroup. The brush organs of Calycopidina and Strymon are similar in structure (Robbins \& Nicolay 2002) with the posterior ends sometimes fused (Figs. 1-2). The lateral edge of the female $8^{\text {th }}$ tergum is heavily sclerotized 


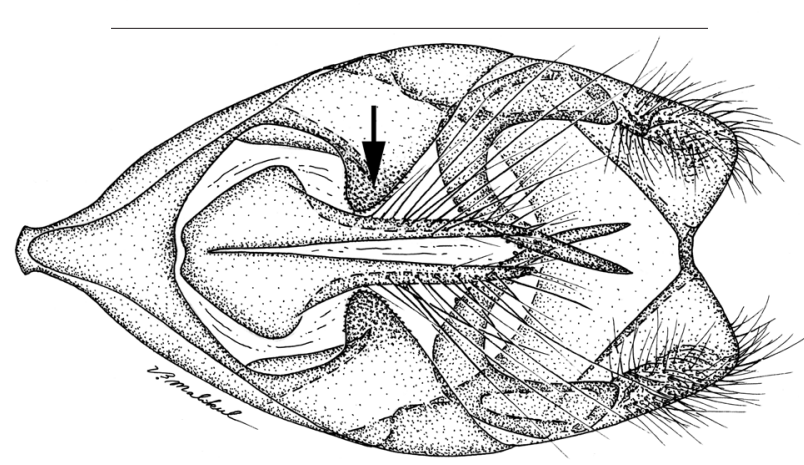

Fig. 5. Ventral aspect of male genitalia showing ventro-lateral processes of vinculum with teeth (arrow) in Arzecla arza (Mexico). Dorsal brush organs removed for clarity. Posterior of insect at right. Scale $1 \mathrm{~mm}$.

in most species of Calycopidina and is lightly sclerotized in some Strymon (Figs. 16-23). These traits are otherwise unreported in the Eumaeini. The other outgroup genera have not been proposed as close relatives of the Calycopidina based on morphology (Robbins 2004b).

The characters used in the phylogenetic analysis are listed in Table II, and the state for each Calycopidina and outgroup species was recorded in Nexus Data Editor (web available software from R.D.M. Page) (Table I). Polymorphic character states were coded with a slash (/) and inapplicable states with a dash (-). Some characters that vary primarily among the outgroup genera were added to resolve different outgroup topologies (Nixon \& Carpenter 1993). All characters were unordered. We coded 22 characters of the male genitalia (including the $8^{\text {th }}$ tergum), 14 of the female genitalia (including the $8^{\text {th }}$ tergum), and 11 of the wings and head. To reduce the number of most parsimonious trees, we made a smaller matrix by removing species that had the same coding as another species. In the cladograms (Figs. 60-61) and Table $\mathrm{I}$, taxa representing more than one species are noted with one asterisk (*) for each additional species with identical coding.

We searched for equal-weight most parsimonious trees with NONA 2.0 in WinClada 1.00.08 (Goloboff 1999; Nixon 2002) using mult* $\mathrm{N}=10$ with 30,000 trees retained in memory. Bootstrap support values for nodes were determined using mult* $\mathrm{N}=10$ with 1,000 replications and 1,000 max trees. We derived a strict consensus of the equal-weight most parsimonious trees. We also tried 5,000 replications and 5 trees saved per replication as an alternative to insure that we were not missing a shorter tree. To test the assumption of equally weighted characters, we used the implied weighting option of TNT (Goloboff et al. 2003) with the "traditional search" option, and memory set at 50,000 trees, 10 replications, and 5,000 saved trees per replication. We used a variety of fit functions $(\mathrm{k}=3,10,25,100,1000)$ and derived a strict consensus tree for each value of $\mathrm{k}$. We used the "unambiguous changes only" option in WinClada to optimize character state changes on the cladograms. We used the "map common synapomorphies" option of TNT to determine unambiguous synapomorphies in all most parsimonious trees under each weighting option.

The taxonomic results include lists of studied taxa,
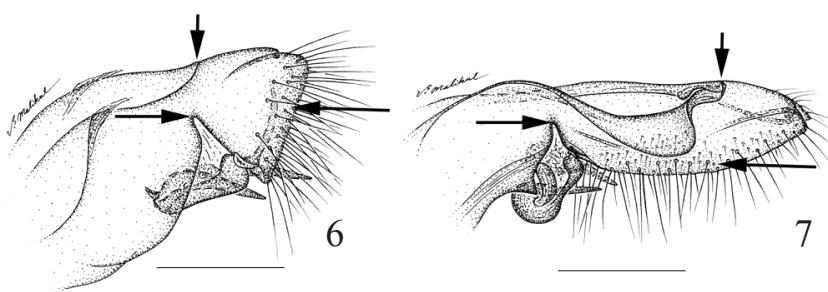

Figs. 6-7. Lateral aspect of male genitalia, showing apex of lateral window (arrow on left), the anterior medial edge of the tegumen (arrow on top) and labides (arrow on right). Posterior of insect at right; 6, Lamprospilus orcidia (Peru), brush organs removed for clarity; 7, Kisutam syllis (Honduras). Scale $0.5 \mathrm{~mm}$.

nomenclatural notes, subtribal and generic diagnoses based on unambiguous changes on the resulting cladograms, and an identification key to the genera based on characters of both sexes. Genera are delimited using the concepts of monophyly and, secondarily, taxonomic stability (Robbins \& Henson 1986; Robbins 2004a). Those species excluded from the phylogenetic analyses (usually because the female is unknown or unrecognized) are listed with a question mark (?) in the genus with which they share synapomorphies. Those species that cannot be placed definitively are noted with a double question mark (??), often with a short parenthetical explanation why placement is uncertain. Synonymies of available species names are listed in Robbins (2004b). Illustrations of major synapomorphies for the subtribe and genera are cited or figured herein. Representative adult males and females are illustrated.

\section{RESULTS}

\section{Phylogenetic Analyses}

After removing taxa with identical coding, the matrix had 69 taxa (including the six outgroups) and 47 characters. With 10 replications, 30,000 equal-weight most parsimonious trees were retained with 170 steps, a consistency index of 46, and a retention index of 84 . With 5,000 replications, the shortest trees were also 170 steps. We illustrate an equal-weight most parsimonious tree (Fig. 60) with optimized character state changes. The strict consensus tree (Fig. 61) was 186 steps. There were 594 implied weight most parsimonious trees with $\mathrm{k}=10,25,100,1000$, each of which was one of the 30,000 equal-weight most parsimonious trees (Fig. 60 is an example). The strict consensus for each value of $\mathrm{k}$ was topologically identical to the equal-weight most parsimonious tree illustrated (Fig. 60) except for five polytomies in the terminal branches. The implied weight trees with $\mathrm{k}=3$ rooted the ingroup in the middle of Electrostrymon and were not among the equal-weight most parsimonious trees. The anomalous rooting may be a consequence of the difficulty in coding characters applicable to the Calycopidina in a relatively distantly related outgroup.

\section{Taxonomy}

Calycopidina Duarte \& Robbins, New Subtribe

Diagnosis. We distinguish the Calycopidina from the remainder of the Eumaeini by a sclerotized inwardly curved 


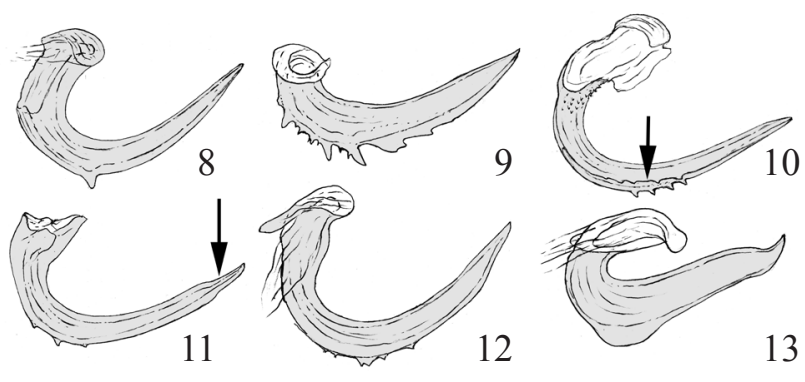

Figs. 8-13. Detail of male genitalia right gnathos; 8, Lamprospilus collucia with a single tooth; 9, Badecla badaca with a single row of medium sized teeth; 10, Arzecla arza with two rows of small teeth (arrow points to second row); 11, Arumecla galliena with one row of small teeth at base (arrow shows apiculate gnathos tip); 12, Camissecla charichlorus with a single row of small teeth; 13, Calycopis cecrops with a single flattened ridge.

edge of the female $8^{\text {th }}$ tergum (Figs. 16-23, State 1 of Character 24 ) and by lack of androconia on the wings (Figs. 40-59, State 0 of Character 37). The modification of the female $8^{\text {th }}$ tergum is unrecorded elsewhere in the Eumaeini. According to the phylogenetic results (Figs. 61), it has been secondarily "lost" in Ziegleria and a few species of Electrostrymon. Lack of androconia distinguishes the Calycopidina from the outgroups, but it also occurs widely in other Eumaeini that lack the other synapomorphies for the Calycopidina. Although fan-shaped signa (Figs. 24-37, State 1 of Character 27) does not occur in the outgroups of the Calycopidina, it is not an "unambiguous synapomorphy" because the transformation series of which it is part can be optimized in different ways. If it were coded instead as present or absent, it would then be an unambiguous synapomorphy. Fan-shaped signa have been secondarily "lost" in some Electrostrymon, Arzecla, and Calycopis; in all such cases the corpus bursae is less than $2 \mathrm{~mm}$ in length (Fig. 39, Character 26, although the corpus bursae is membranous, this character was unambiguously scored in virtually every case).

Nomenclature. The type genus of Calycopidina is Calycopis Scudder, 1876, and the name is formed in accord with the requirements and recommendations of the International Code of Zoological Nomenclature (ICZN, 1999). K. Johnson \& Kroenlein (1993b) used "infratribe" names Angulopina and Calycopina for some genera that we include in the Calycopidina, but these names are unavailable because they were introduced after 1930 without an indication of how they differ from related taxa (Articles 13.1 and 13.2 in ICZN, 1999).

Taxonomy. The Calycopidina generic classification of Robbins (2004b) is modified in three ways. First, Lamprospilus as delimited in Robbins (2004b) is not monophyletic in all most parsimonious trees (e.g., it is paraphyletic in Fig. 60). Dividing this concept of Lamprospilus requires fewer new combinations than enlarging it. We partition Lamprospilus into Lamprospilus, Arzecla, and Badecla, each of which is monophyletic in the consensus tree (Fig. 61). We recognize Badecla because bootstrap supports for Lamprospilus and for
Badecla are more than twice that of the combined lineage of these two genera (Fig. 61).

Second, we divide the previous concept of Ziegleria into Ziegleria and Kisutam K. Johnson \& Kroenlein. Even though the previous concept of Ziegleria is monophyletic in the phylogenetic results (Node A in Fig. 60), the highly derived genitalia of Kisutam make it difficult to place this genus systematically. Ziegleria and Kisutam, as classified in this paper, each have a higher bootstrap value and more synapomorphies than the previous concept of Ziegleria, for which reason this classification is more likely to be stable in the future.

Third, we divide the previous concept of Electrostrymon into Electrostrymon and Rubroserrata K. Johnson \& Kroenlein. Even though the previous concept of Electrostrymon is monophyletic in the phylogenetic results (Node B in Fig. 60), this node is supported by a bootstrap value of 5 (Fig. 61). Electrostrymon and Rubroserrata, as classified in this paper, each have higher bootstrap values and are easily differentiated in the field by wing pattern.

Included Genera (generic synonymy below). Lamprospilus Geyer, 1832; Badecla Duarte \& Robbins, new genus; Arzecla Duarte \& Robbins, new genus; Arumecla Robbins \& Duarte, 2004; Camissecla Robbins \& Duarte, 2004; Electrostrymon Clench, 1961; Rubroserrata K. Johnson \& Kroenlein, 1993, revalidated status; Ziegleria K. Johnson, 1993; Kisutam K. Johnson \& Kroenlein, 1993, revalidated status; Calycopis Scudder, 1876.

Recognition. As noted in the diagnoses, the most distinctive synapomorphies for the Calycopidina occur in the female abdomen. Although many Calycopidina species have phenotypically similar wing patterns, for which reason related species have often been grouped together (e.g., Draudt 1919-1920), there are no wing pattern characters by which Calycopidina can be recognized. Probably the best superficial recognition character for males is lack of androconia, even though this condition occurs widely elsewhere in the Eumaeini. Dorsally fused brush organs (Fig. 2) and teeth or a ridge on the gnathos (Figs. 8-13) are other recognition traits for male Calycopidina.

Size and Sexual Dimorphism. Calycopidina adults are small to medium sized Eumaeini, with forewing lengths ranging from about $8.5 \mathrm{~mm}$ (e.g., small individuals of Arzecla taminella [Schaus]) to about $20 \mathrm{~mm}$ (e.g., males of Lamprospilus decorata). Wing pattern sexual dimorphism varies from marked (Figs. 40-43, 58-59) to minimal (Figs. $46-47,52-57)$.

Distribution and Habitat. Calycopidina occur from temperate North America (C. cecrops [Fabricius]) to temperate South America (e.g., Badecla argentinensis [K. Johnson \& Kroenlein 1993]), from rain forest (e.g. Lamprospilus aunus [Cramer]) to "cactus" desert (e.g., Electrostrymon joya [Dognin]), and from sea level (e.g., Camissecla charichlorus [Butler \& H. Druce]) to more than 

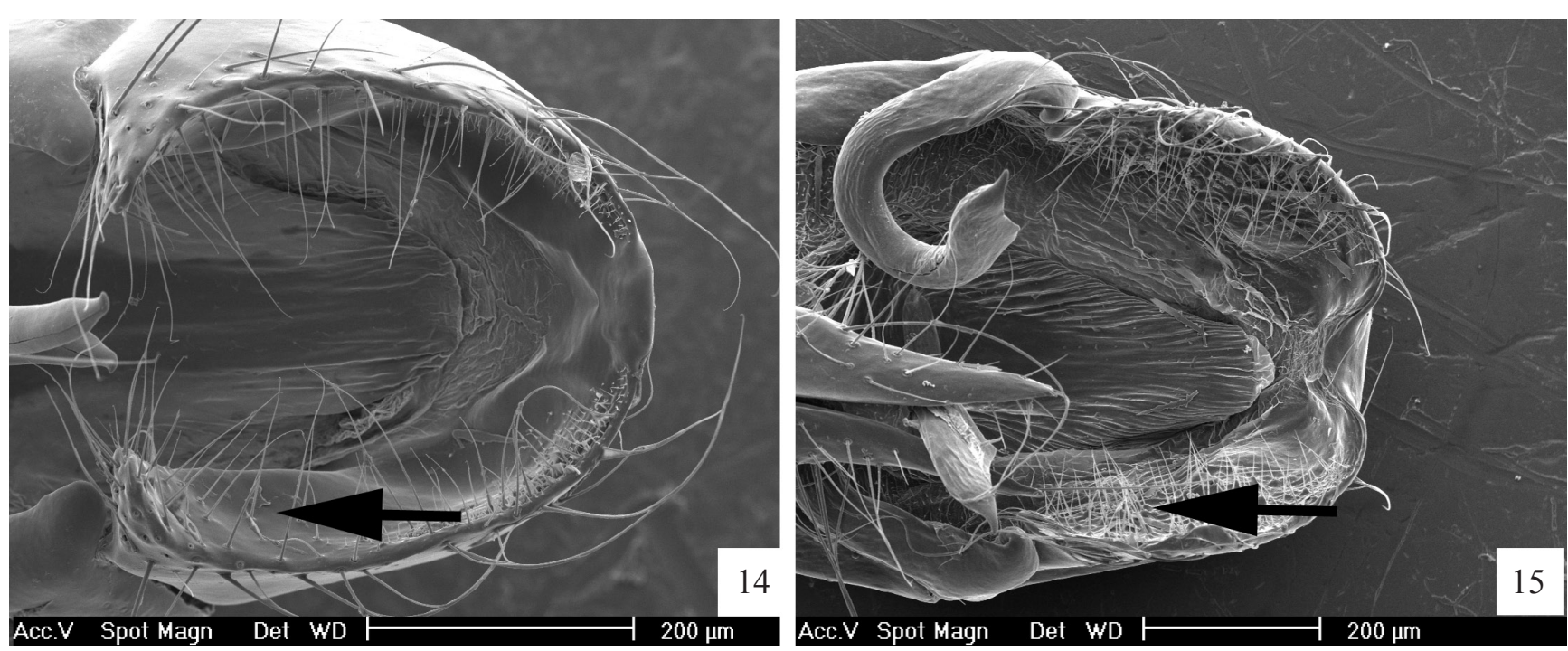

Figs. 14-15. SEM of Calycopis labides in ventral aspect; 14, Smooth surface in Calycopis demonassa (arrow); 15, Ridges in Calycopis pisis (arrow).

2,000 m elevation (e.g., Camissecla pactya [Hewitson]). In lowland rain forest, Calycopis species often comprise the major part of the understory Lycaenidae fauna.

Seasonality and Abundance. The dorsal and ventral wing patterns of the one widespread North American Calycopidina species (C. cecrops) are seasonally variable (detailed in Field 1967a: 18-19). Seasonality in Neotropical species is less well documented, but "dry season" adults often have a lighter ventral wing pattern than "wet season" individuals (Robbins et al. in prep.). Many Neotropical Calycopidina species become conspicuously more common towards the end of the dry season (March-April in Panama, September-October in Amazonian Peru, Robbins et al. 1996), which may be related to their detritivorous habit. In southeastern Brazil, abundance of Lycaenidae, including Calycopidina, increases markedly at the end of the southern summer (February-April) (K. Brown 1992).

Key to the Calycopidina Genera (based primarily on unique synapomorphies, but both sexes are needed to place a species in a genus)

1. Orange-red spot (rarely dark brown) distal of the postmedian line in hindwing cell $\mathrm{Cu}_{2}-2 \mathrm{~A}$ (some individuals of Camissecla camissa will key here but they may easily be distinguished by absence of regularly-spaced piliform setae on ventral hindwing veins 2A and 3A) (Figs. 56-59) ............... Calycopis

No orange-red spot distal of the postmedian line in hindwing cell $\mathrm{Cu}_{2}-2 \mathrm{~A}$ .. 2

2(1'). Inner and outer surfaces of gnathos tip vertically flattened Ziegleria

Inner and outer surfaces of gnathos tip conical ......... 3

3(2'). Labides width in lateral aspect considerably greater than height (Figs. 7) .... Kisutam revalidated status

Labides width in lateral aspect equal or less than height $4\left(3^{\prime}\right)$. With fan-shaped signa that are about twice as long as wide (Fig 30) Camissecla

Fan-shaped signa, if present, not longer than wide ... 5

5(4'). Dorsal wings with a semi-circle of chalk-blue scales at the inner margin (D'Abrera, 1995:1234-1235 illustrations of Thecla cleon and T. mathewi) .......... Rubroserrata revalidated status

Dorsal wings without a semi-circle of chalk-blue scales at the inner margin ..... .. 6

$6\left(5^{\prime}\right)$. Two (or more) rows of small teeth on the gnathos (Fig. 10) Arzecla new genus

One row of teeth or no teeth on gnathos 7

$7\left(6^{\prime}\right)$. A few small teeth only on the basal half of the gnathos, which have an apiculate tip (Fig. 11) ....... Arumecla Without small teeth on the basal half of the gnathos . 8

$8\left(7^{\prime}\right)$. With orange-red piliform scales on male frons

Badecla new genus

Without orange-red piliform scales on male frons .... 9

$9\left(8^{\prime}\right)$. With a single medium-sized tooth on the gnathos (Fig.8)

Lamprospilus Without a single medium-sized tooth on the gnathos ..... Electrostrymon

\section{Lamprospilus Geyer, 1832}

Diagnosis. We distinguish Lamprospilus from the remainder of the Calycopidina by one medium sized tooth in the middle of the male genitalia gnathos (poorly developed in L. coelicolor) (Fig. 8, State 1 of Character 3), by a dark brown patch at the base of the ventral hindwing in males only (Figs. 40-43, State 1 of Character 39), and by ventral forewing with a dark postmedian band in males only (Figs. 40-43, State 1 of character 47). The first synapomorphy distinguishes 


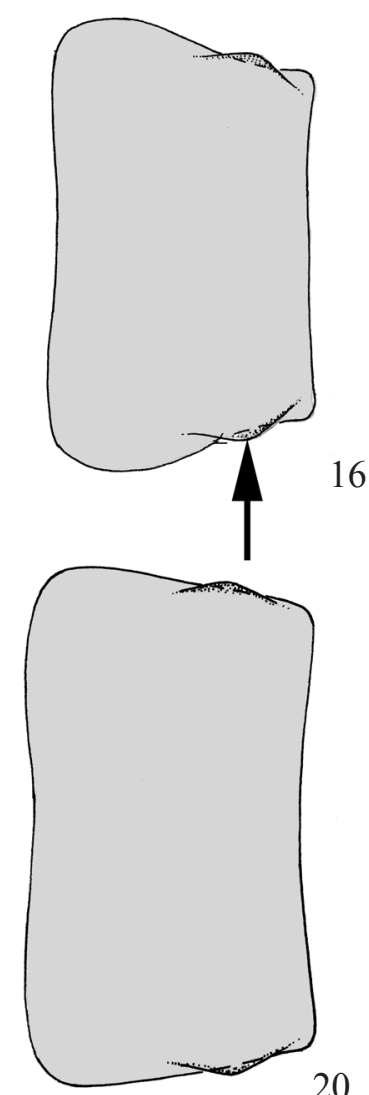

20

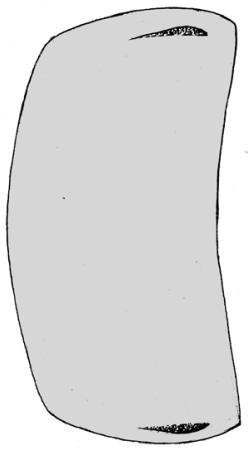

17

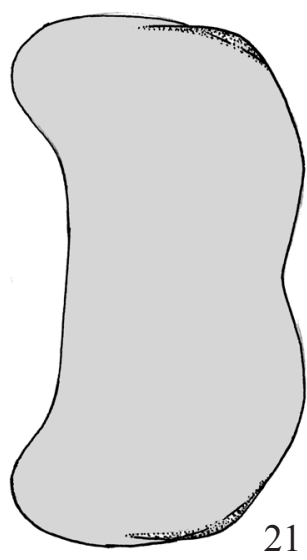

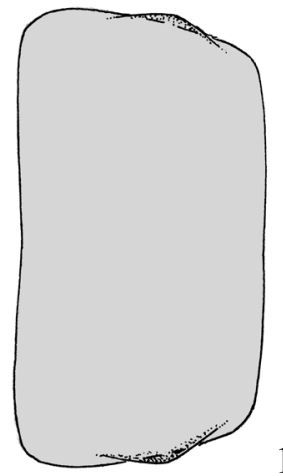

18

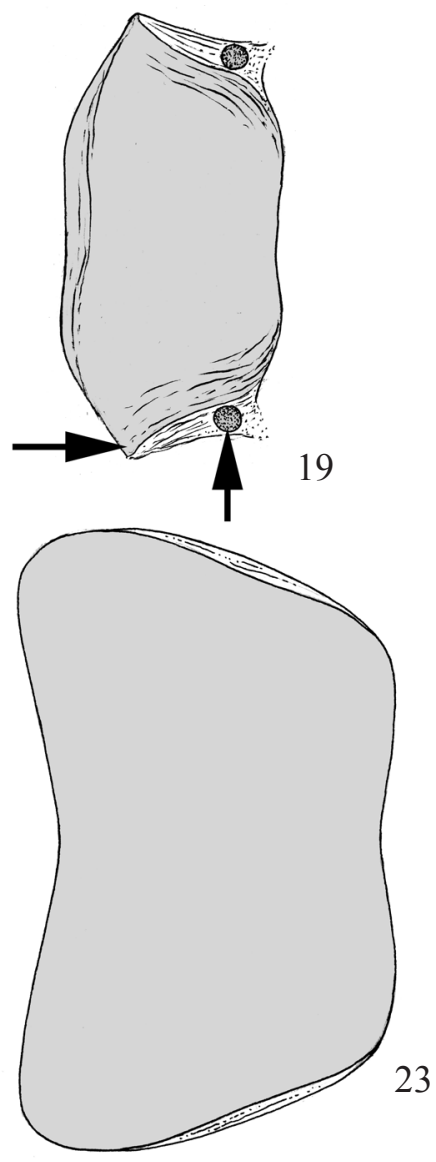

Figs. 16-23. Dorsal aspect of female $8^{\text {th }}$ tergum, posterior of insect at right; 16, Lamprospilus genius (Peru), showing curved sclerotization at lateral edge (arrow); 17, Arzecla arza (Peru); 18, Arumecla aruma (Ecuador); 19, Ziegleria hesperitis (Panama) without sclerotization, but with anterior lateral processes (arrow at left) and with sclerite posterior of the tergum (arrow at right); 20, Electrostrymon endymion (Brazil); 21, Calycopis cecrops (United States); 22, Strymon melinus (Venezuela), showing simple sclerotization at lateral edge (arrow); 23, Strymon ziba (Mexico). Scale 0.5mm.

Lamprospilus unambiguously from the remainder of the Eumaeini, so far as we are aware, and the latter two distinguish it from most Eumaeini.

Nomenclature. The type species of Lamprospilus is Lamprospilus genius Geyer, 1932. Gigantorubra K. Johnson, 1993 is treated as a junior synonym of Lamprospilus because its type species, L. collucia (Hewitson, 1877), possesses the three synapomorphies for Lamprospilus in the phylogenetic results.

Taxonomy. Gigantorubra, as previously characterized (K. Johnson 1993a; Austin \& K. Johnson 1997), is polyphyletic in the phylogenetic results, containing two species of Lamprospilus, three species of Badecla, one species of Arumecla, one of Ziegleria, and one of Kisutam.

Included Species. Lamprospilus genius Geyer (Figs. 40-41), L. japola (Jones), L. decorata Lathy(?), L. nicetus (C. Felder \& R. Felder), L. draudti Lathy, L. occidentalis K. Johnson \& Salazar?, L. collucia (Hewitson), L. orcidia (Hewitson), L. aunus (Cramer) (Figs. 42-43), L. coelicolor (Butler \& H. Druce). There are another four or five undescribed species that belong to Lamprospilus.

Distribution and Habitat. Lamprospilus occurs in wet and dry lowland and montane forest from Mexico to southern Brazil and central Argentina.

Remarks. Lamprospilus species have markedly sexually dimorphic wing patterns (Figs. 40-43), and in many cases, males and females were described as different species (cf. synonymies in Robbins 2004b) and placed in different genera or species groups (Draudt 1919-1920; D’Abrera 1995). Lamprospilus was traditionally restricted to males that had white or hyaline longitudinal bands across the dorsal and ventral wings (Lathy 1932; D’Abrera 1995) (Fig. 40), a monophyletic grouping-after one species with white bands in both sexes (Thecla azaria Hewitson) was moved to another section of the Eumaeini (Robbins, 2004b) - in the phylogenetic results (Node A in Fig. 61). As characterized in the phylogenetic results, some Lamprospilus males are blue or brown on the dorsal wings without white bands (e.g., Fig. 42).

\section{Badecla Duarte \& Robbins, New Genus}

Diagnosis. We distinguish Badecla from the remainder of the Calycopidina by orange-red piliform setae on the male frons (State 1 of Character 44), a trait that occurs sporadically throughout the Eumaeini. Badecla is also the only Eumaeini genus to have a row of medium size teeth (Fig. 9, State 2 of 

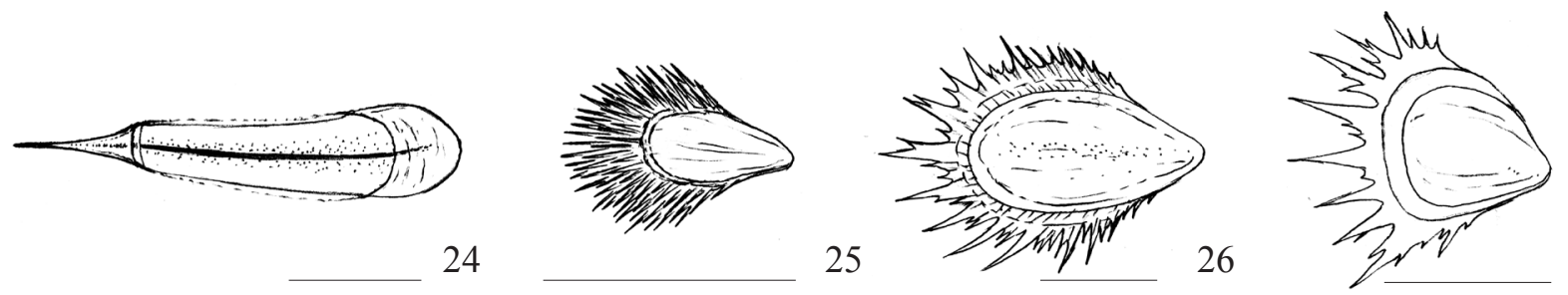

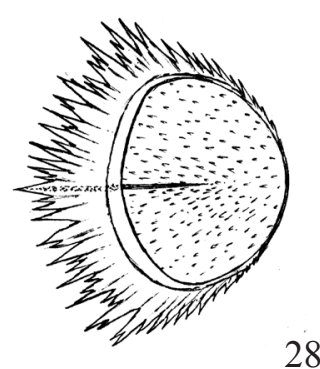

28

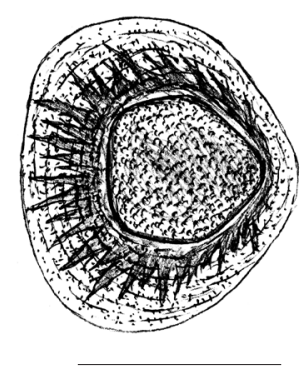

29
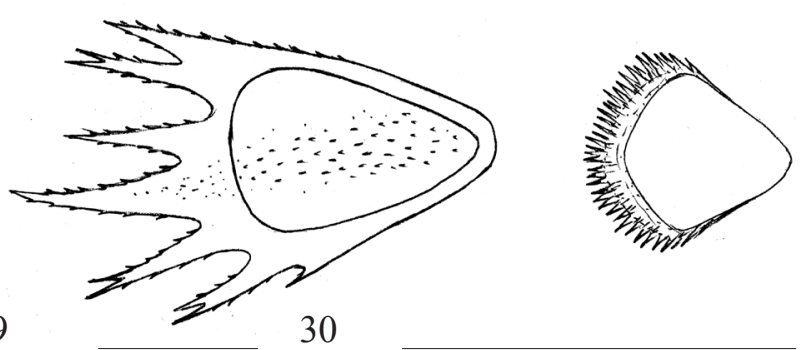

31
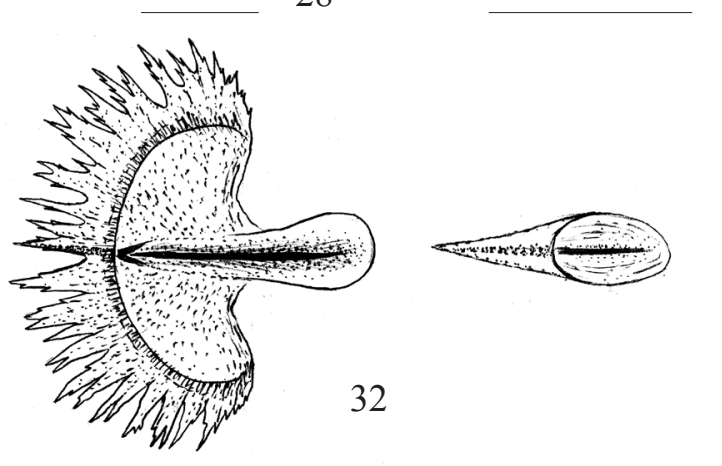

32
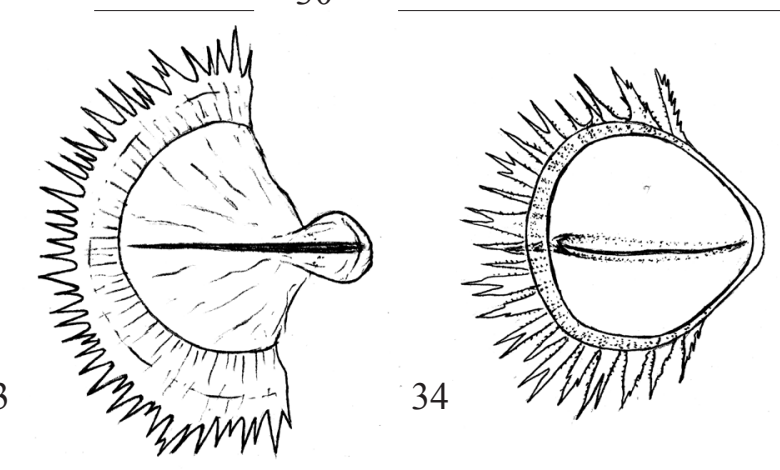

Figs. 24-35. Female genitalia signa in external aspect, posterior of insect at right; 24, Strymon melinus, not fan-shaped; 25, Lamprospilus genius, no spine; 26, Badecla badaca, with vestigial spine; 27, Arzecla arza, no spine; 28, Arzecla canacha, no spine; 29, Arumecla aruma, no spine, anterior rays within sclerotized "circle"; 30, Camissecla camissa, twice as long as wide with vestigial spine; 31, Electrostrymon endymion, vestigial, shape variable; 32, Ziegleria hesperitis, posteriorly constricted, with spine; 33, Electrostrymon guzanta, vestigial, shape variable; 34, Calycopis tamos, posteriorly constricted, with spine; 35 , Calycopis cecrops, with spine. Scale $0.2 \mathrm{~mm}$.

Character 2 and State 3 of Character 3) on the male genitalia gnathos. Genitalic structures are homogeneous within Badecla and are similarly homogeneous within Lamprospilus. The monophyly of Lamprospilus + Badecla is less certain than that of each genus separately, as indicated by lower bootstrap support values (Fig. 61).

Nomenclature. The type species of Badecla is Thecla badaca Hewitson, 1868. The generic name is feminine and is an arbitrary combination of "badaca" and Thecla".

Taxonomy. The ventral wing pattern of $L$. badaca is highly variable geographically, but available evidence suggests that this variation is clinal.

Included Species. Badecla badaca (Hewitson) new combination (Figs. 44-45), B. picentia (Hewitson)? new combination, $B$. quadramacula (Austin \& K. Johnson)? new combination, $B$. lanckena (Schaus) new combination, $B$. argentinensis (K. Johnson \& Kroenlein) new combination, and $B$. clarissa (Draudt) new combination.

Distribution and Habitat. Badecla occurs in wet and dry lowland and montane forest in South America east of the
Andes from Venezuela to northern Argentina and southern Brazil.

Remarks. Interspecific genitalic variation in Badecla is negligible. Wing pattern sexual dimorphism is minimal in $B$. argentinensis and $B$. clarissa, but pronounced in the other species, in which the sexes have sometimes been described as different species.

\section{Arzecla Duarte \& Robbins, New Genus}

Diagnosis. We distinguish Arzecla from the remainder of the Calycopidina by two or more rows of small teeth on the male genitalia gnathos (Fig. 10, State 1 of Character 5) and by the posterior ventro-lateral edge of the vinculum-tegumen with a process with teeth on the ventral surface (Fig. 5, State 1 of Character 12, secondarily "lost" in two species Figs. 60-61).

Nomenclature. The type species of Arzecla is Thecla arza Hewitson, 1874. The generic name is feminine and is an arbitrary combination of "arza and Thecla".

Included Species. Arzecla arza (Hewitson) new combination (Figs. 46-47), A. tarpa (Godman \& Salvin) new combination, A. canacha (Hewitson) new combination, 

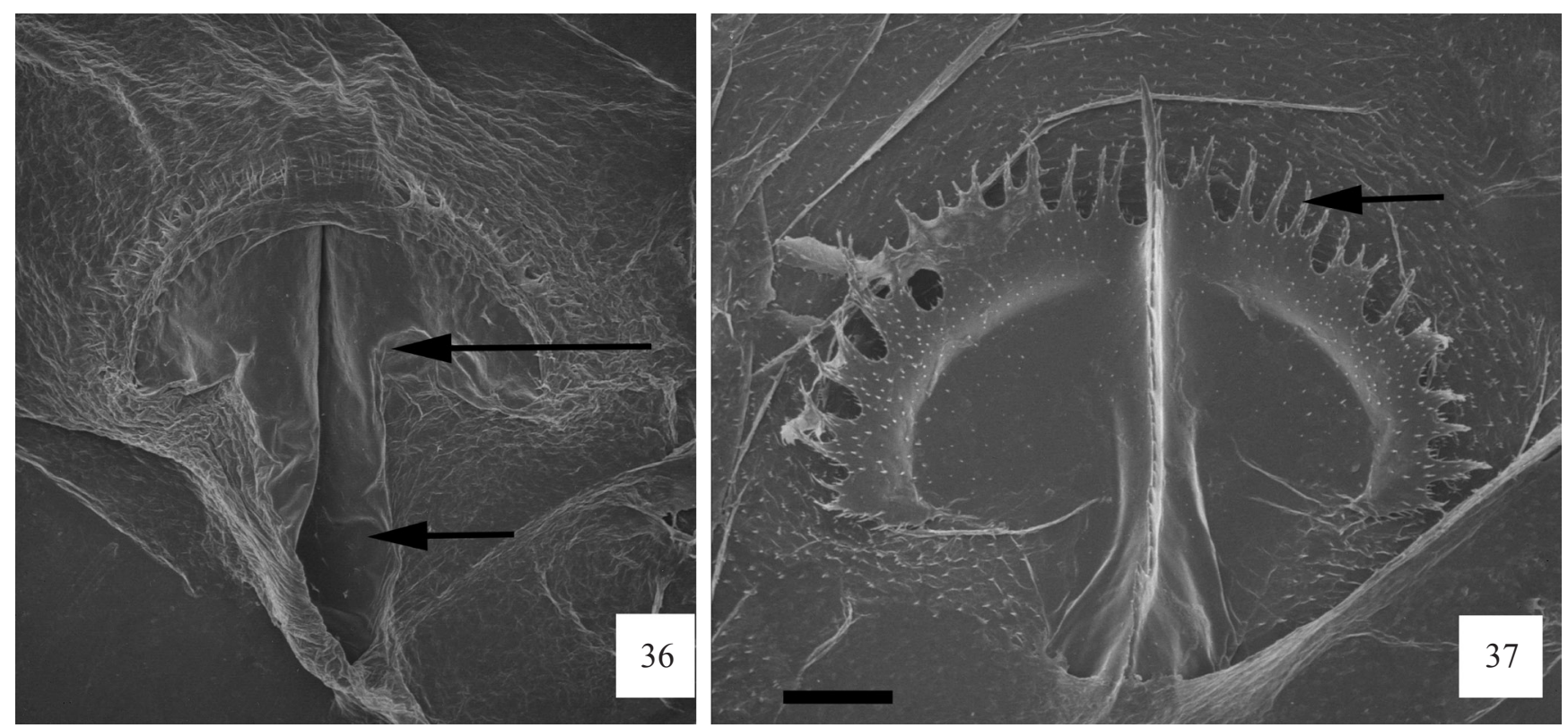

Figs. 36-37. SEM of Ziegleria hesperitis female genitalia signa, posterior of insect at bottom; 36, External surface, showing aperture in the wall of the corpus bursae (lower arrow) and posterior constriction (upper arrow); 37, Internal surface, showing rays on inside of the corpus bursae (arrow). Scale 100 $\mu \mathrm{m}$.

A. calatia (Hewitson)? new combination, A. tucumanensis (K. Johnson \& Kroenlein) new combination, A. sethon (Godman \& Salvin) new combination, A. nubilum (H. H. Druce) new combination, A. paralus (Godman \& Salvin) new combination, A. taminella (Schaus) new combination, and $A$. albolineata (Lathy) new combination.

Distribution and Habitat. Arzecla occurs in wet and dry lowland and montane forest from Mexico to northern Argentina and southern Brazil.

Remarks. Wing pattern sexual dimorphism is minimal throughout Arzecla, in marked contrast to Lamprospilus. Males are brown dorsally (Figs. 46-47) except for $A$. albolineata, which is muted blue. Those Arzecla species with conspicuous alternating light and dark bands on the ventral wings of both sexes (Figs. 46-47) have long been treated as closely related to each other (Draudt 1919-1920). Although they form a monophyletic group within the genus (Node B in Fig. 61), the genitalic similarities between $A$. albolineata (without the alternating bands) and $A$. paralus and $A$. taminella (with the alternating bands), especially Characters 13 and 15 , suggest the alternative hypothesis that these three species are more closely related than their position in the cladograms. Finally, the genitalic structures of A. canacha are highly autapomorphic.

\section{Arumecla Robbins \& Duarte, 2004}

Diagnosis. We distinguish Arumecla from the remainder of the Calycopidina by one row of small teeth near the base of the male genitalia gnathos (Fig. 11, State 2 of Character 3) and by gnathos with apiculate tips $0.75-1.35 \mathrm{~mm}$ long (Fig.
11, State 1 of Character 6; see also Robbins \& Duarte 2004) that are thicker than those that occur in some Electrostrymon species.

Nomenclature. The type species of Arumecla is Thecla aruma Hewitson, 1877.

Included Species. Arumecla aruma (Hewitson) (Figs. 48-49), A. galliena (Hewitson), A. nisaee (Godman \& Salvin, 1887), and A. netesca (Draudt)?? (the placement of this species is provisional because of its autapomorphic male genitalia). There are a substantial number of rare, poorlyknown undescribed species, especially in Andean montane forest, that appear to belong to Arumecla.

Distribution and Habitat. Arumecla occurs in wet lowland and montane forest from Mexico to southern Brazil.

Remarks. Males of described species are blue dorsally, and the sexes are somewhat dimorphic (Figs. 48-49).

\section{Camissecla Robbins \& Duarte, 2004}

Diagnosis. We distinguish Camissecla from the remainder of the Calycopidina by fan-shaped signa about twice as long as wide (Fig. 30, State 1 of Character 29). Other synapomorphies in the implied weight trees (Fig. 60 is an example) are anterior base of brush organs on the ventral part of the genital capsule (Fig. 4, State 2 of Character 15, secondarily "lost" in C. pactya, Figs. 60) and signa with less than 15 rays pointing anteriorly (Fig. 30, State 1 of Character 29; "U"-shaped signa of Robbins \& Duarte 2004), which occurs widely in other Calycopidina.

Nomenclature. The type species of Camissecla is Thecla camissa Hewitson, 1870. 


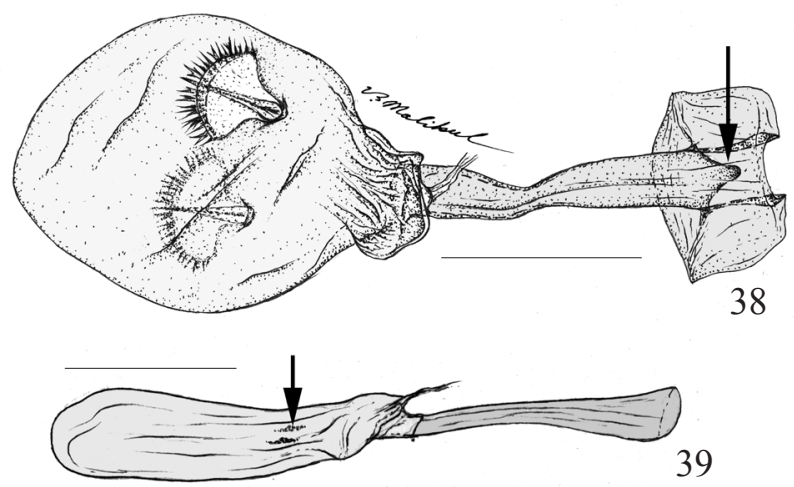

Figs. 38-39. Female genitalia ductus copulatrix, posterior to right; 38, Ziegleria hesperitis (Panama) in dorsal aspect, showing the corpus bursae $>2 \mathrm{~mm}$ in length, the sclerotized posterior ventral end of the ductus bursae with a posterior pointing process (arrow). The ductus seminalis arises dorsal of the ductus bursae. Scale 1mm; 39, Electrostrymon joya (Ecuador) in lateral aspect, showing corpus bursae $<2 \mathrm{~mm}$ in length and vestigial signa (arrow). Scale $0.5 \mathrm{~mm}$.

Included Species. Camissecla charichlorus (Butler \& $\mathrm{H}$. Druce), C. simasca (Draudt), C. gedrosia (Hewitson)?? (the type has an aberrant wing pattern, and identification of this species is provisional), C. camissa (Hewitson) (Figs. 50-51), C. cleocha (Hewitson), C. pactya (Hewitson), C. vespasianus (Butler \& H. Druce), C. melma (Schaus), C. saphronotis (K. Johnson \& Kroenlein), C. vesper (H. H. Druce), and $C$. verbenaca $(\mathrm{H}$. H. Druce)?. There are at least four undescribed species of Camissecla.

Distribution and Habitat. Camissecla occurs in wet lowland and montane forest from Mexico to southern Brazil.

Remarks. Wing pattern sexual dimorphism in Camissecla is slight (Figs. 50-51), and associating males and females is not difficult except in a few cases where sympatric females are phenotypically very similar (e.g., C. charichlorus and $C$. melma). Interspecific wing pattern variation is sometimes slight, which has caused identification problems, such as distinguishing $C$. camissa from $C$. charichlorus. The extent and hue of male dorsal blue color is intraspecifically variable in some species, especially one of the undescribed taxa.

\section{Electrostrymon Clench, 1961}

Diagnosis. We distinguish Electrostrymon by male genitalia gnathos without teeth (State 0 of Character 2 and State 0 of Character 3) and by male dorsal wings with conspicuous copper scales (Fig. 52, State 1 of Character 43). These synapomorphies are homoplastic within the Calycopidina (Fig. 60), but all Electrostrymon species also share a corpus bursae less than $2 \mathrm{~mm}$ long (Fig. 39, State 1 of Character 26) and vestigial signa (Figs. 31, 39, State 2 of Character 27).

Nomenclature. The type species of Electrostrymon is Papilio endymion Fabricius, 1775. The type species of Angulopis K. Johnson and Pendantus K. Johnson \& Kroenlein possess the synapomorphies of Electrostrymon. Their type species, respectively, are Thecla autoclea Hewitson (a subjective synonym of Polyommatus hugon) and Thecla plusios Godman \& Salvin (a subjective synonym of Tmolus denarius Butler \& H. Druce). The recently discovered type of $E$. hugon shows that this name applies to the species previously called E. sangala (Hewitson) (Faynel \& Bálint 2004).

Taxonomy. Previous concepts of Angulopis and Pendantus were polyphyletic in the phylogenetic results. Angulopis as previously characterized (K. Johnson \& Kroenlein 1993a; Austin \& K. Johnson 1997; Canals \& K. Johnson 2000) contained five species of Lamprospilus, three species of Camissecla, three of Ziegleria, and one of Electrostrymon. Pendantus as previously characterized (K. Johnson \& Kroenlein 1993) contained one species of Lamprospilus and one of Electrostrymon. Robbins (2004b) placed the type species of Pendantus in Ziegleria, which is falsified by the phylogenetic results.

Electrostrymon denarius, E. guzanta, and E. perisus form a morphologically homogenous group that has highly derived genitalic structures (Figs. 60), for which reason it has been difficult to place this group systematically. Preliminary analysis of molecular sequences does not provide a definitive placement, but is consistent with its placement in Electrostrymon (Quental et al. in prep.). The alternative of placing these species in the available generic name Pendantus is inadvisable because it would leave Electrostrymon paraphyletic (Figs. 60-61).

Included Species. Electrostrymon endymion (Fabricius) (Figs. 52-53), E. constantinoi (K. Johnson \& Kroenlein), E. hugon (Godart), E. joya (Dognin), E. dominicana (Lathy), E. pan (Drury)?, E. angelia (Hewitson), E. angerona (Godman \& Salvin), E. denarius (Butler \& H. Druce) new combination, E. guzanta (Schaus) new combination, and E. perisus (H. H. Druce) new combination.

Distribution and Habitat. Electrostrymon occurs in dry and wet lowland and montane forest from Mexico to southern Brazil. It is the only genus of Calycopidina to occur in the Antilles, with four endemic species. Electrostrymon species tend to be very common insects, especially in xeric areas and at the end of the dry season in wetter habitats, but $E$. constantino $i$ is an exception, being known from less than ten museum specimens from dry areas in northern Venezuela and eastern Colombia. Males of Electrostrymon occupy "mating territories" in the morning from sunrise to 0930 hours (E. endymion, E. hugon) as well as just before sunset (E. endymion).

Remarks. Electrostrymon males have conspicuous orangecopper scaling on the dorsal wing surface that is partially or wholly lacking in females (Figs. 52-53), but this scaling is not diagnostic because it occurs occasionally in other Calycopidina (e.g., Arzecla paralus) and other eumaeines (e.g., some geographical forms of Satyrium favonius [J. E. Smith]). The wing pattern of E. hugon in western Colombia 

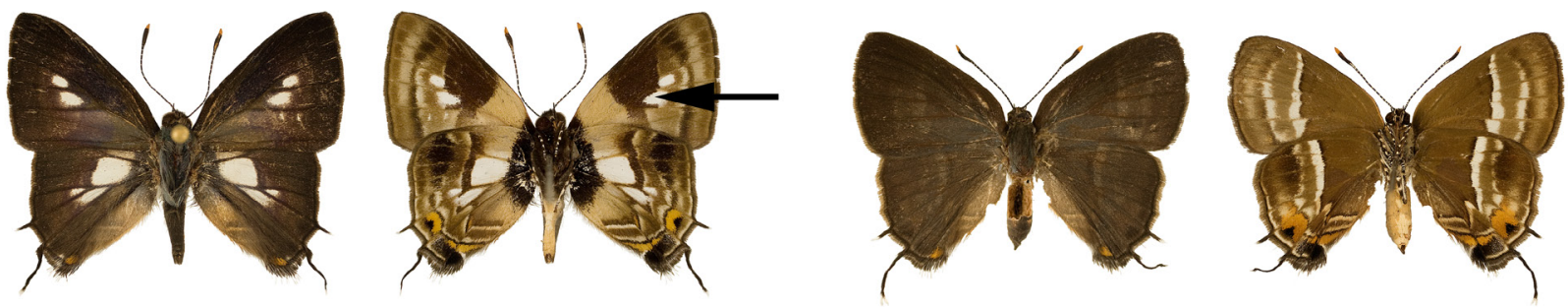

40
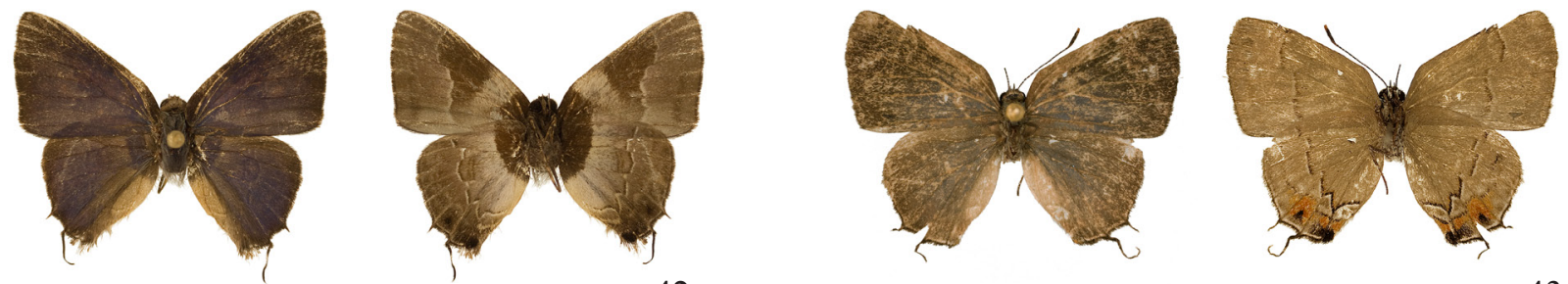

42
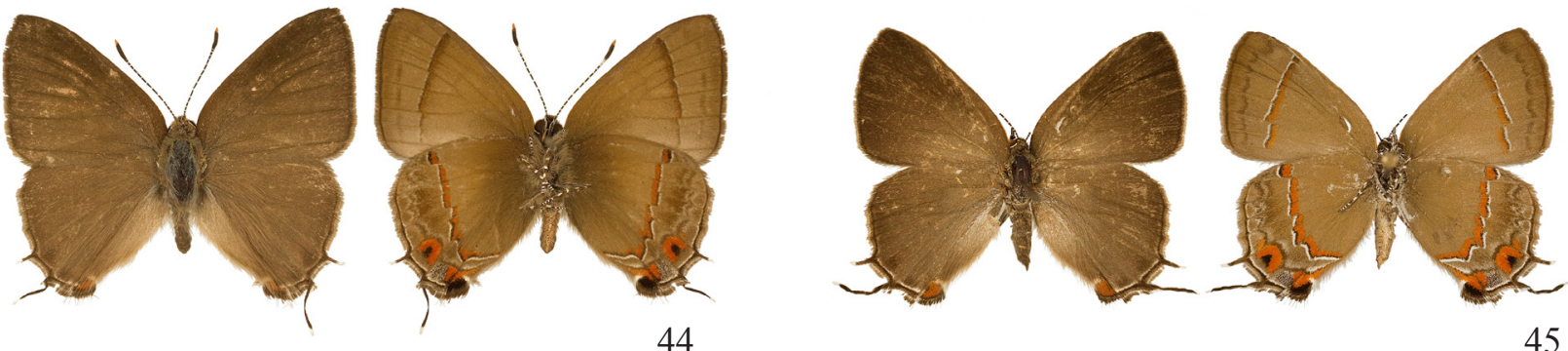

45
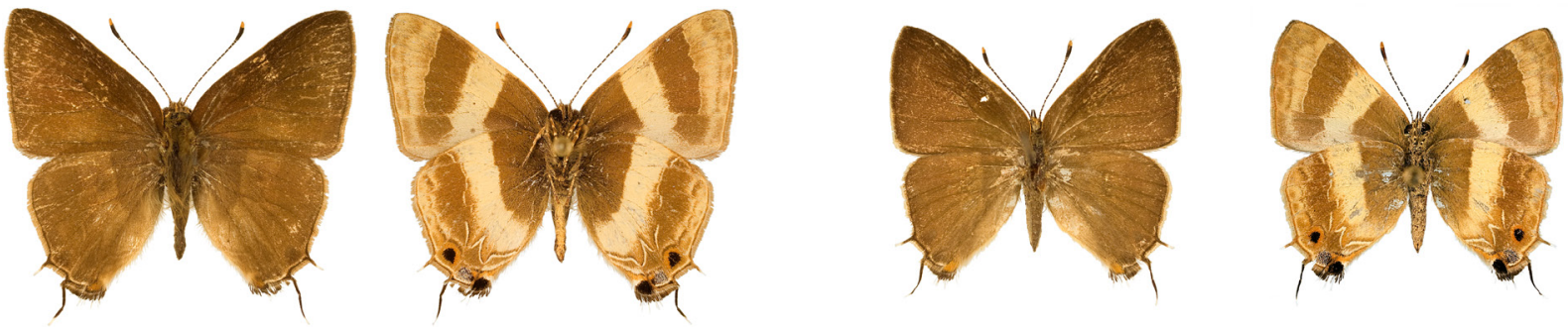

46
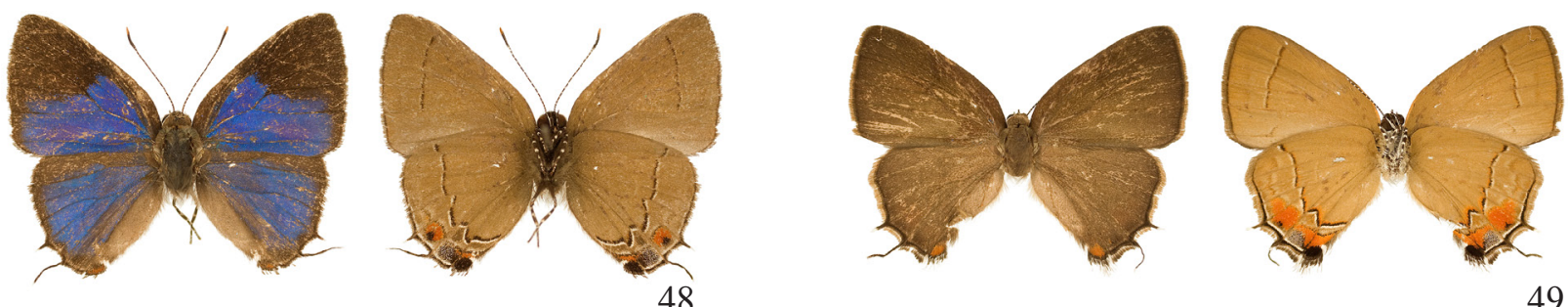

49

Figs. 40-49. Adults, dorsal surface on left, ventral on right; 40, Male Lamprospilus genius (Peru) with semi-transparent hyaline spots (arrow); 41, Female $L$. genius (Peru) without hyaline spots; 42, Male Lamprospilus aunus (French Guiana); 43, Female L. aunus (Peru); 44, Male Badecla badaca (Brazil, Rio de Janeiro); 45, Female B. badaca (Brazil, Rio de Janeiro); 46, Male Arzecla arza (Nicaragua); 47, Female $A$. arza (Nicaragua); 48, Male Arumecla aruma (in copula, Ecuador); 49, Female $A$. aruma (in copula with previous male).

has more extensive orange-red scaling on both dorsal and ventral wing surfaces than in other parts of its range.

The wing pattern and genitalia of E. joya are variable geographically, and it is yet unclear whether this variation would support the hypothesis that E. joya consists of more than one biological species.

\section{Rubroserrata K. Johnson \& Kroenlein, 1993, Revalidated Status}

Diagnosis. We distinguish Rubroserrata from the remainder of the Calycopidina by the ventro-lateral edge of vinculum/tegumen with a small process with teeth primarily 

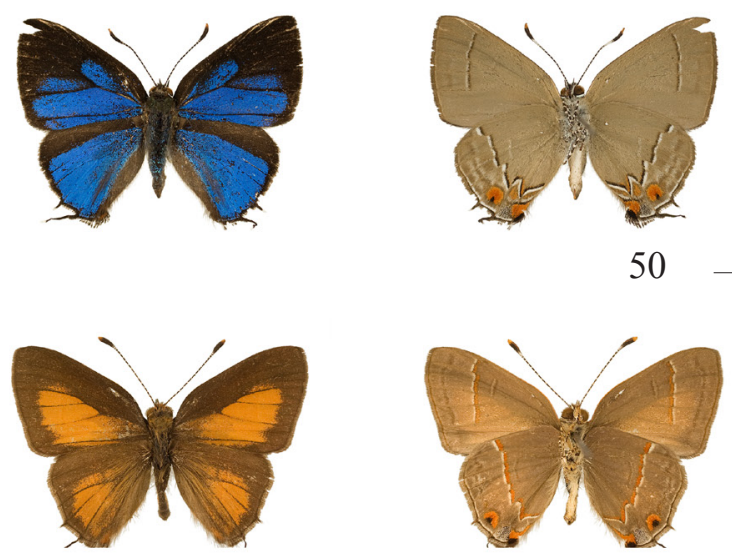

52
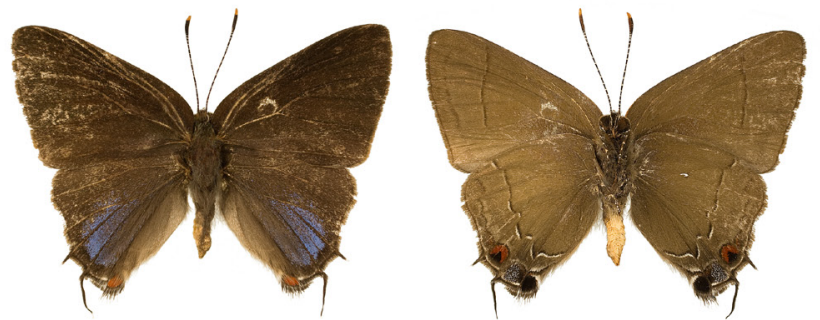

54
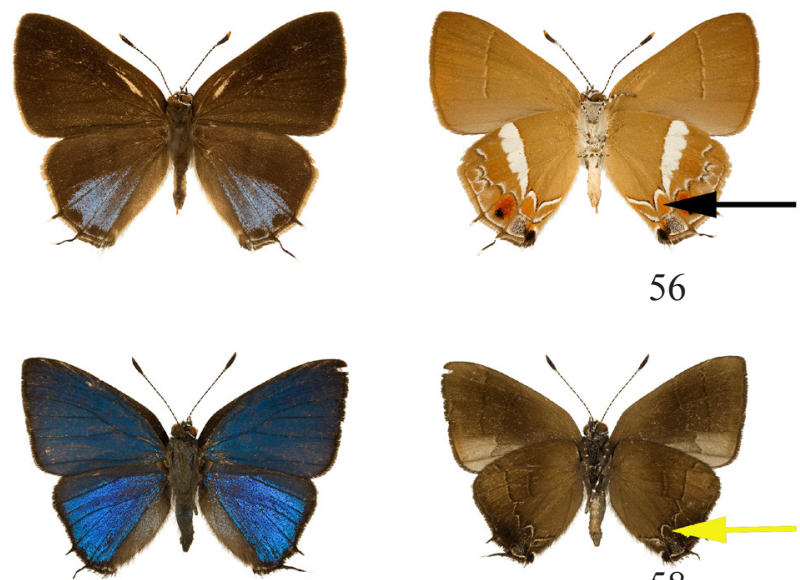

56

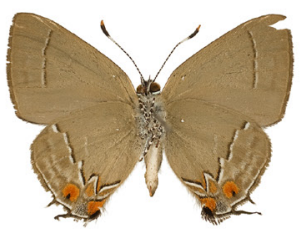

50

$1 \mathrm{~cm}$
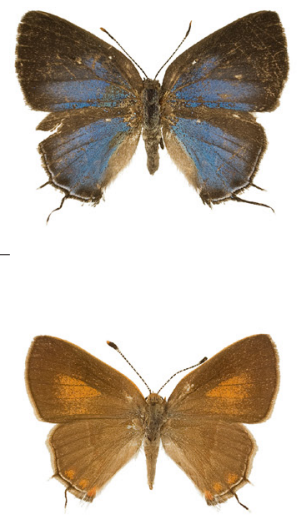

51

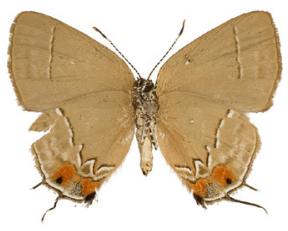

51

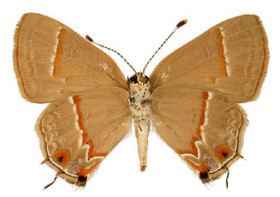

53
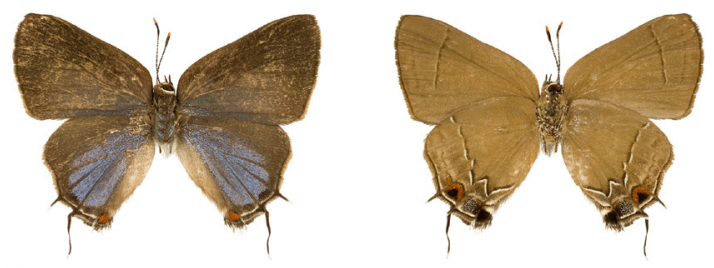

55
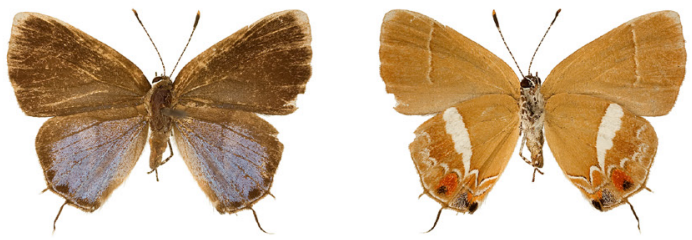

57
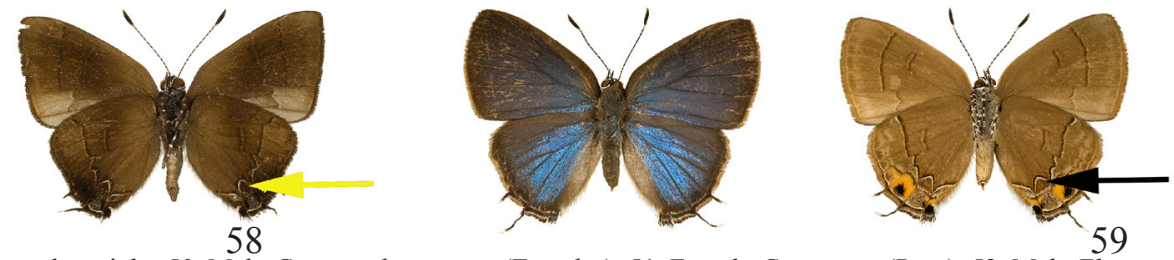

Figs. 50-59. Adults, dorsal surface on left, ventral on right; 50, Male Camissecla camissa (Ecuador); 51, Female C. camissa (Peru); 52, Male Electrostrymon endymion (Brazil, Paraiba); 53, Female E. endymion (Brazil, Paraiba); 54, Male Ziegleria hesperitis (in copula, Panama); 55, Female Z. hesperitis (in copula with previous male); 56, Male Calycopis tamos (Panama) with orange-red spot in cell $\mathrm{Cu}_{2}-2 \mathrm{~A}$ (arrow); 57, Female C. tamos (Panama); 58, Male Calycopis xeneta (Western Ecuador) with dark brown spot in cell $\mathrm{Cu}_{2}-2 \mathrm{~A}$ (arrow); 59, Female C. xeneta with only a few orange-red scales in cell $\mathrm{Cu} 2-2 \mathrm{~A}$ (arrow) (Western Ecuador).

on the posterior part (State 2 of Character 12, also occurs in E. joya, Fig. 60) and by male dorsal wings with a semi-circle of chalk-blue scales at the inner margin (State 1 of Character 45), which is unique in the Eumaeini.

Nomenclature. The type species of Rubroserrata K. Johnson \& Kroenlein is Thecla mathewi Hewitson, 1874. Robbins (2004b) treated Rubroserrata as a subjective junior synonym of Electrostrymon.

Taxonomy. Rubroserrata was polyphyletic as previously characterized (K. Johnson \& Kroenlein 1993b), containing two species of Rubroserrata, one of Ministrymon Clench, and one of Dicya K. Johnson. The latter two genera do not belong to the Calycopidina (Robbins 2004b).
Included Species. Rubroserrata mathewi (Hewitson) new combination and $R$. ecbatana (Hewitson) new combination. The latter species has been widely called Thecla cleon (Fabricius) (e.g., Draudt 1919-1920), but the type of T. cleon in the Banks Collection is a superficially similar-looking species that belongs to Ministrymon, not to the Calycopidina (Robbins 2004b).

Distribution and Habitat. Rubroserrata occurs commonly in wet and dry lowland and montane forest from Mexico to southern Brazil. Males of both Rubroserrata species occupy "mating territories" on hilltops in the morning from sunrise to 0930 hours (R. K. Robbins, unpubl.). 


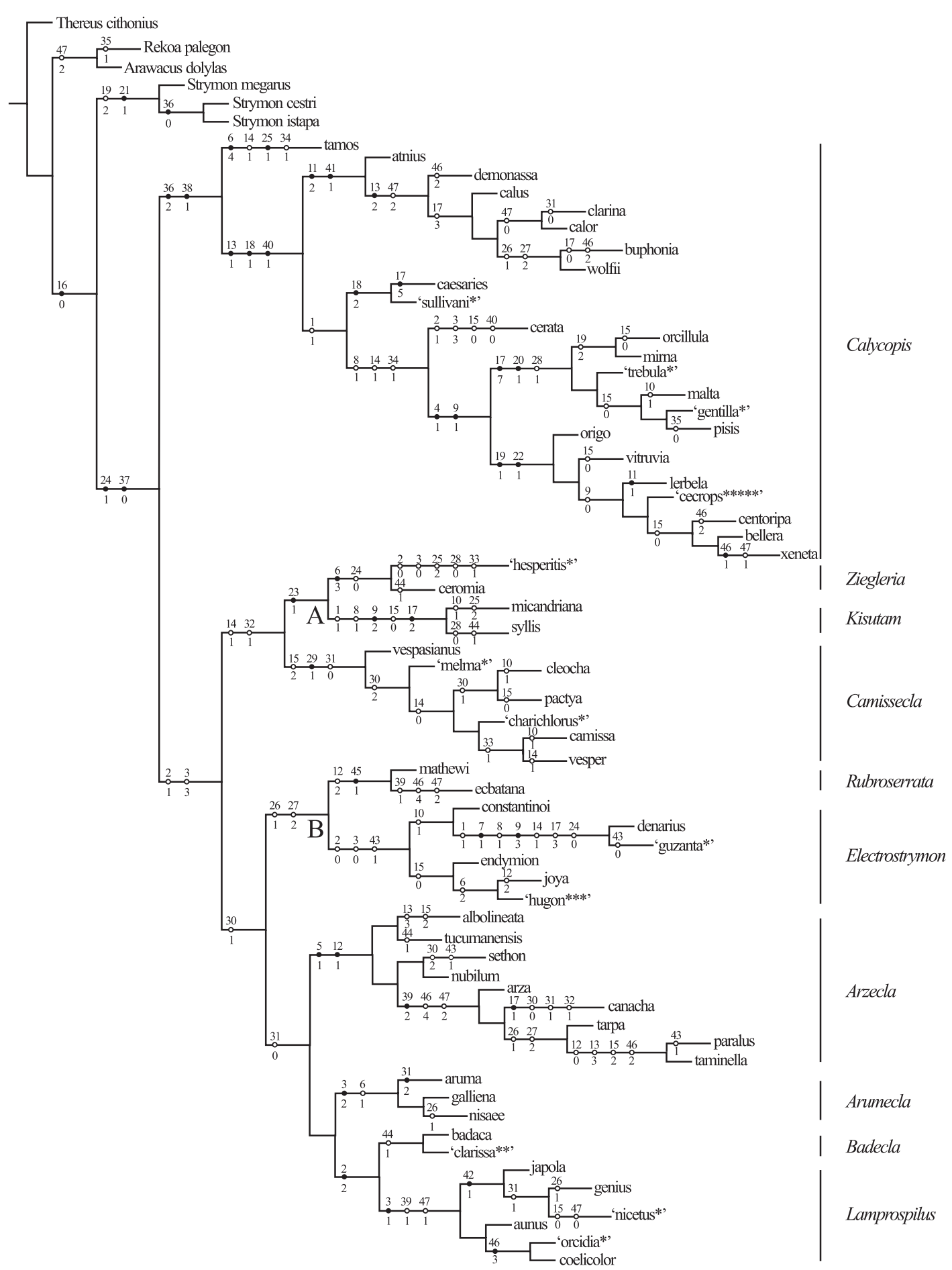

Fig. 60. A most parsimonious tree with equal weights and with implied weights with fit functions ranging from 10 to 1000 . Character numbers are above circles and states below. Solid circles represent states that change once on the cladogram. Each asterisk after a species name indicates a species that was omitted because it had identical coding. Nodes A and B represent the concept of Ziegleria and Electrostrymon, respectively, proposed by Robbins (2004b).

Remarks. As characterized in this paper, Rubroserrata contains one pair of allopatric/parapatric species that share habitat and male behavior with Electrostrymon. However, the row of small teeth on the gnathos (Characters 2 and 3) and the chalk-blue dorsal color dorsally (Character 45) of male Rubroserrata make the monophyly of Electrostrymon + Rubroserrata uncertain, as indicated by a bootstrap support value of 5 for this combined lineage (Fig. 61).

\section{Ziegleria K. Johnson, 1993}

Diagnosis. We distinguish Ziegleria from the remainder of the Calycopidina by the inner and outer surfaces of the male genitalia gnathos vertically flattened (State 3 of Character 6) and lateral edge of female 8th tergum not sclerotized (Fig. 19, State 0 of Character 24). The flattened gnathos tips occur in no other Eumaeini. The $8^{\text {th }}$ tergum lacking sclerotization 


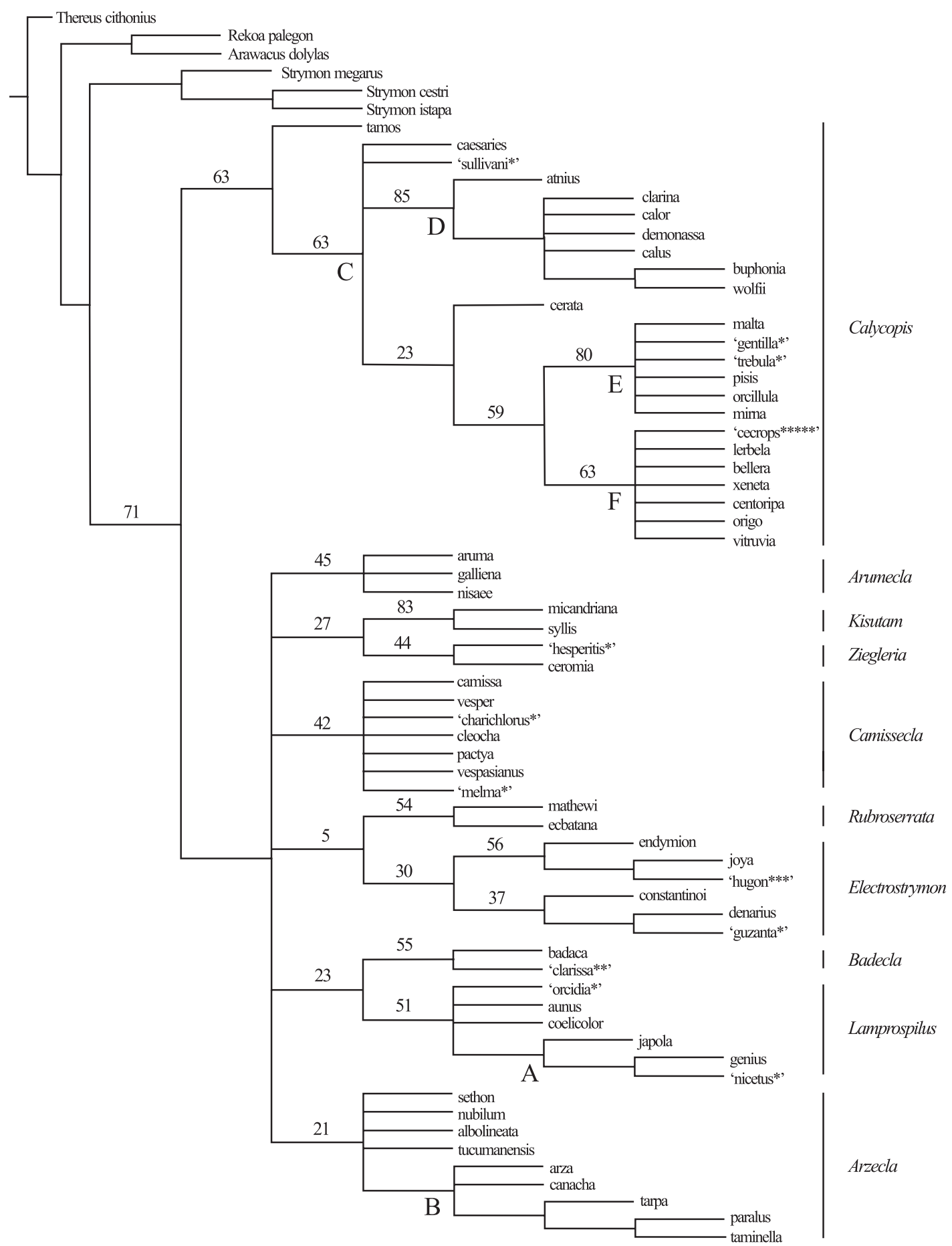

Fig. 61. Strict consensus tree of most parsimonious equal-weight trees. Bootstrap support values above major nodes. Node A represents the lineage of males with white or hyaline bands across the wings, Node B the lineage of species with alternating dark and light bands in both sexes, Node C the lineage of species with piliform setae on ventral hindwing vein $2 \mathrm{~A}$, Node $\mathrm{D}$ the lineage of species with piliform setae on ventral hindwing vein $3 \mathrm{~A}$, Node E the lineage of species with ridges on the inner surface of the male genitalia labides, and Node F the traditional concept of Calycopis (sensu Field, 1967a).

occurs in all non-Calycopidina Eumaeini, but is a reversal in Ziegleria, according to the phylogenetic results (Fig. 60).

Nomenclature. The type species of Ziegleria is $Z$. bernardi K. Johnson, 1993, a subjective synonym of $Z$. hesperitis. Robbins (2004b) accorded Ziegleria priority over Pendantus, but the phylogenetic results (Figs. 60-61) falsify this synonymy (see under Electrostrymon). The name $Z$. hoffmani $\mathrm{K}$. Johnson is misspelled, but it cannot be amended under ICZN article 32.5.1 because Johnson specifically proposed this name for Carlos Hoffman, even though the correct spelling is Carlos Hoffmann (Lamas, pers. comm.).

Taxomony. Ziegleria as delimited in Robbins (2004b) is divided into Ziegleria and Kisutam for reasons already noted. 
Table I. Data Matrix for the Calycopidina. Dimorphisms are noted with a slash (/) and inapplicable states with a dash (-).

Taxa $\quad 0102030405060708091011121314151617181920212223242526272829303132333435363738394041424344454647$

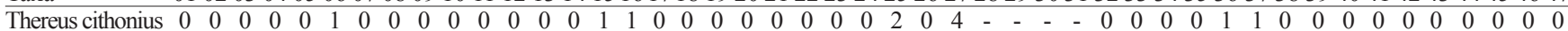

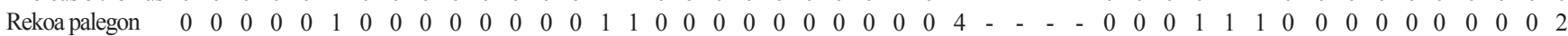

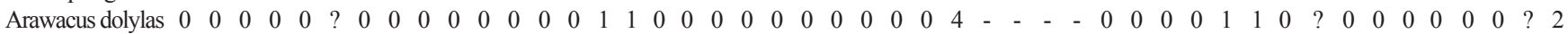
$\begin{array}{llllllllllllllllllllllllllllllllllllllllllllllllllllllllllllllllllllll}\text { Strymon cestri } & 0 & 0 & 0 & 0 & 0 & 2 & 0 & 0 & 0 & 0 & 0 & 0 & 0 & 0 & 1 & 0 & 0 & 0 & 2 & 0 & 1 & 0 & 0 & 0 & 0 & 0 & 0 & - & - & - & - & 0 & 0 & 0 & 0 & 0 & 1 & 0 & 0 & 0 & 0 & 0 & 0 & 0 & 0 & 0 & 0\end{array}$

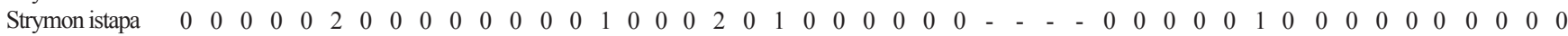

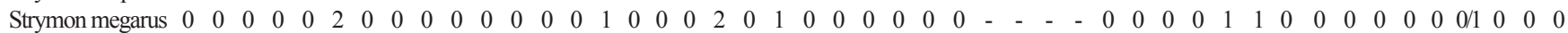
japola

genius

nicetus*

orcidia*

aunus

coelicolor

badaca

clarissa** $^{* *}$

sethon

nubilum

albolineata

tucumanensis

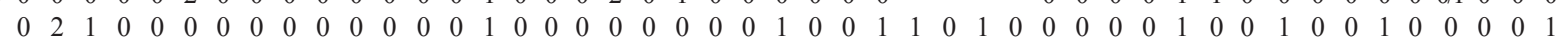

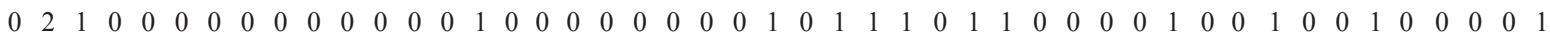

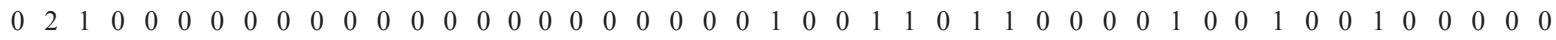

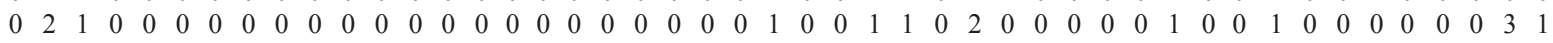

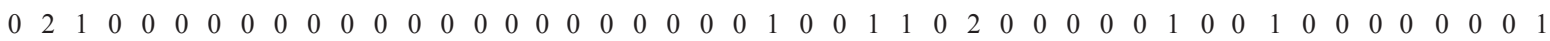

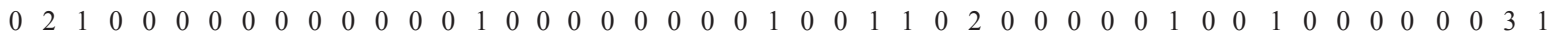

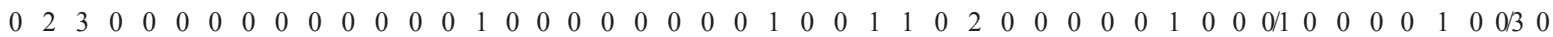

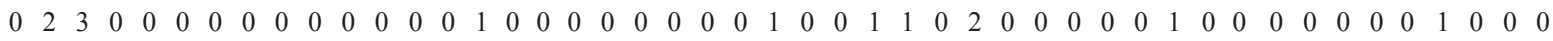

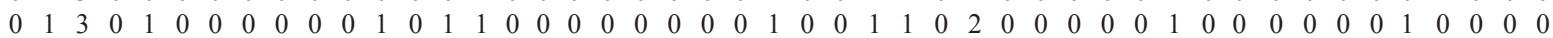

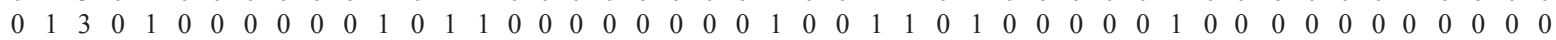

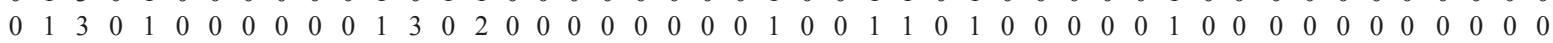
arza

canacha

tarpa

paralus

taminella

aruma

galliena

nisaee

camissa

vesper

charichlorus*

cleocha

pactya

vespasianus

melma*

hesperitis*

ceromia

micandriana

syllis

denarius

guzanta*

mathewi

ecbatana

endymion

constantinoi

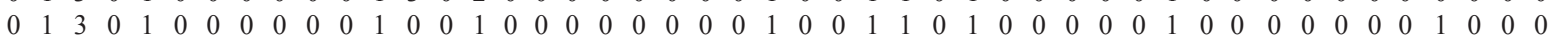

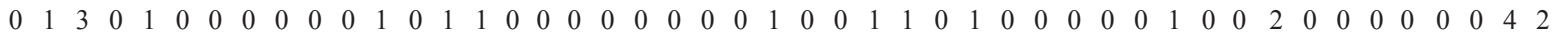
$\begin{array}{llllllllllllllllllllllllllllllllllllllllllllllll}0 & 1 & 3 & 0 & 1 & 0 & 0 & 0 & 0 & 0 & 0 & 1 & 0 & 0 & 1 & 0 & 1 & 0 & 0 & 0 & 0 & 0 & 0 & 1 & 0 & 0 & 1 & 1 & 0 & 0 & 1 & 1 & 0 & 0 & 0 & 1 & 0 & 0 & 2 & 0 & 0 & 0 & 0 & 0 & 0 & 4 & 2\end{array}$

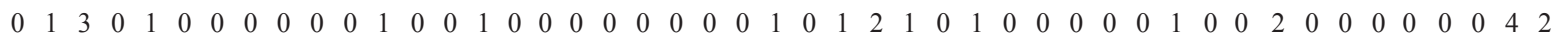

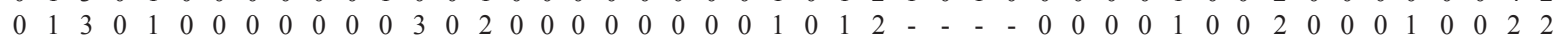

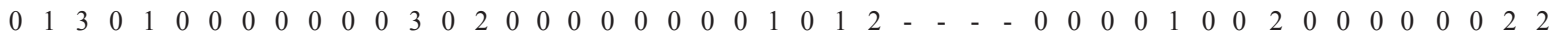

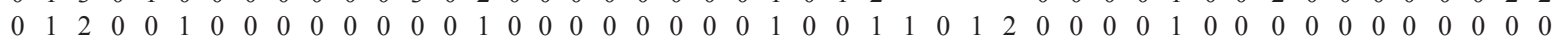

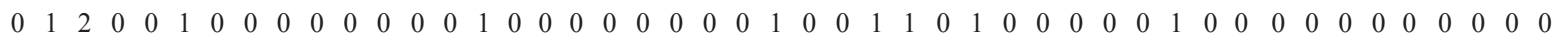

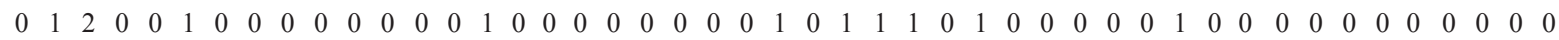

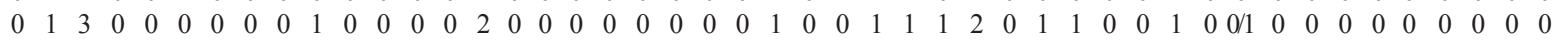

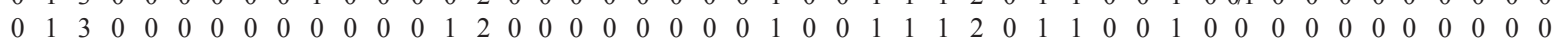

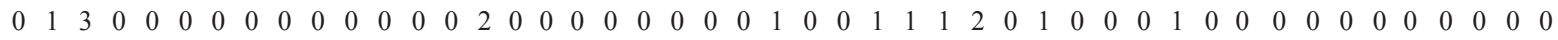

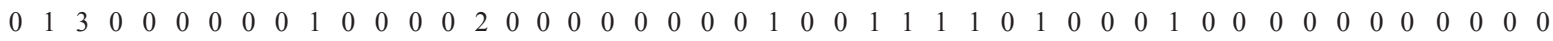

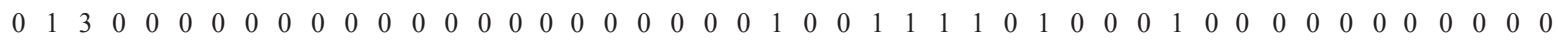

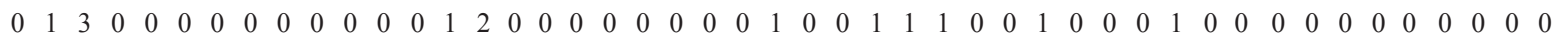

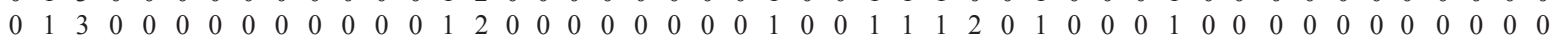

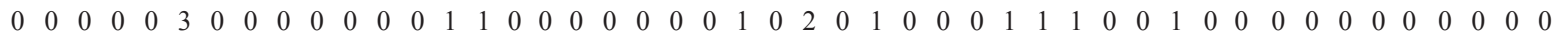

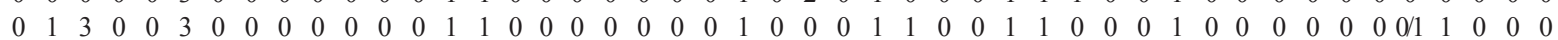

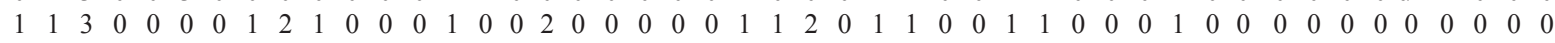

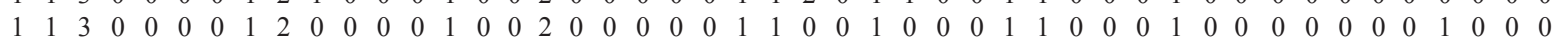

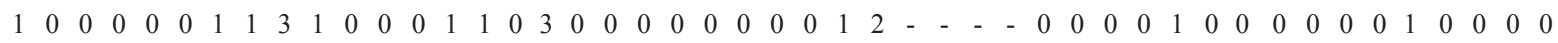

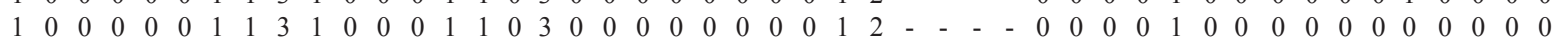

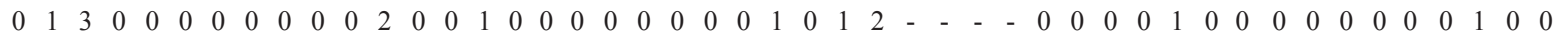

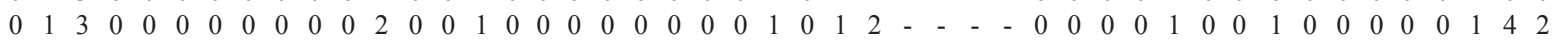

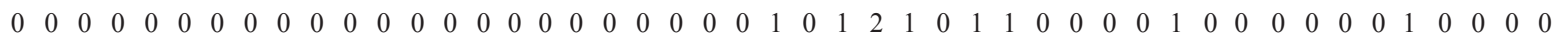
joya hugon*** tamos atnius

clarina

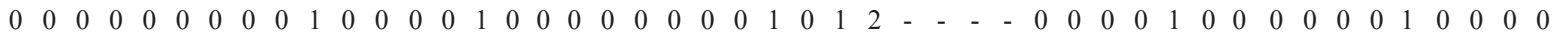

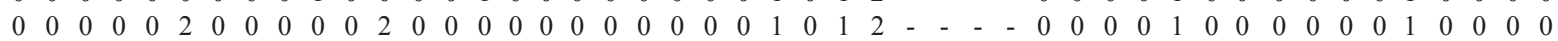

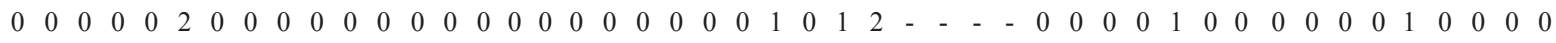

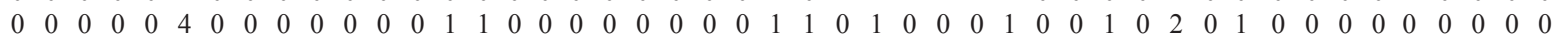

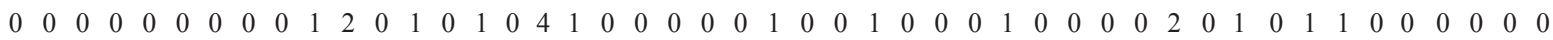

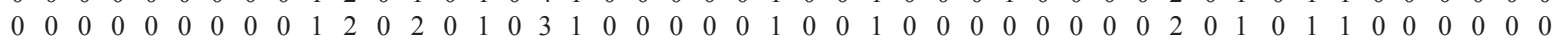

calor

demonassa

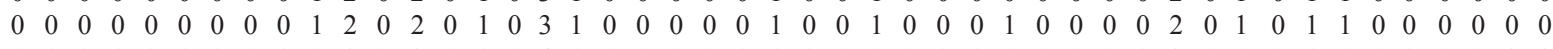

calus

buphonia

wolfii

caesaries

sullivani*

cerata

cecrops $* * * * *$

lerbela

bellera

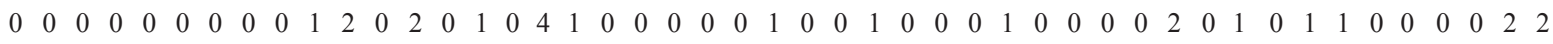

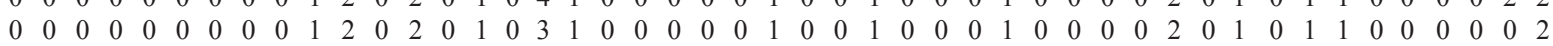

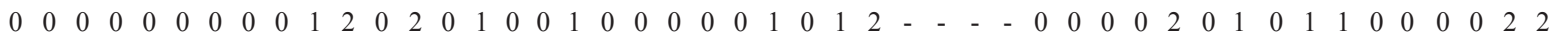

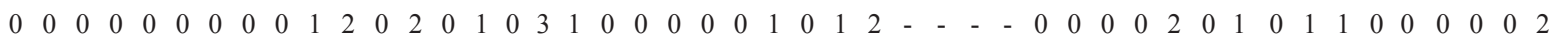

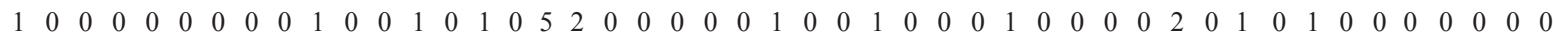

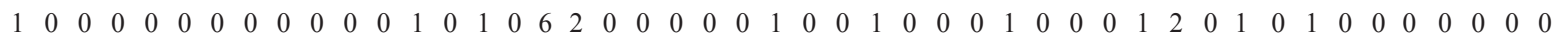

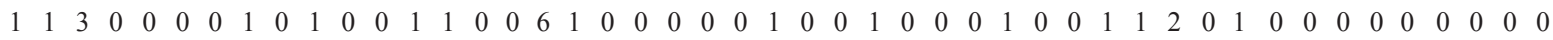

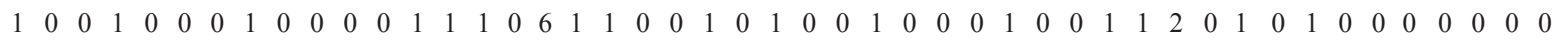

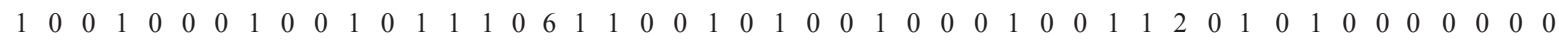

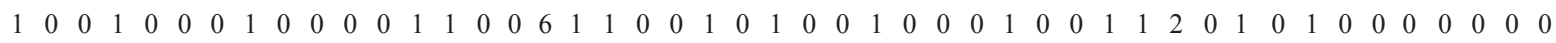

xeneta

centoripa

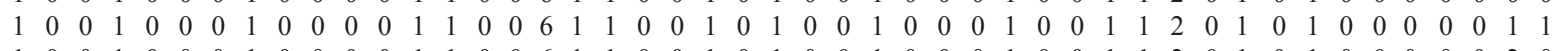

origo

vitruvia

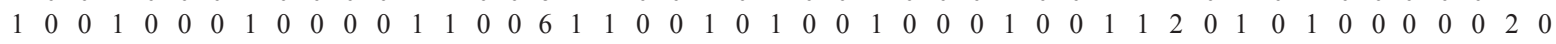

malta

gentilla*

trebula*

pisis

orcillula

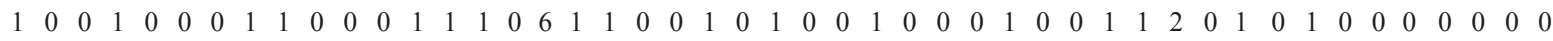

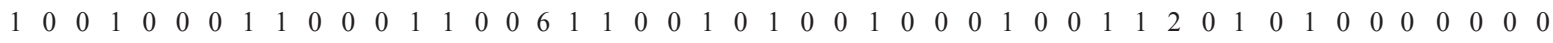

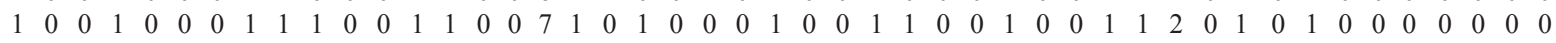

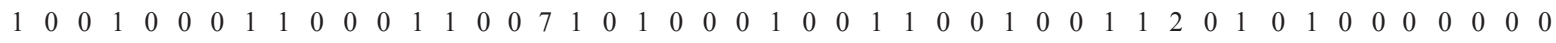

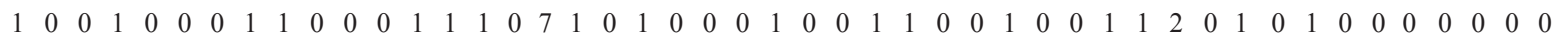

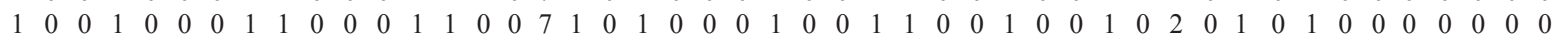

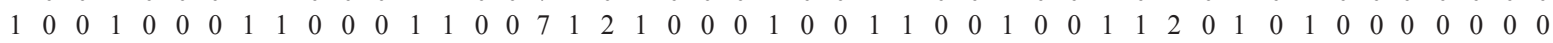
mirna

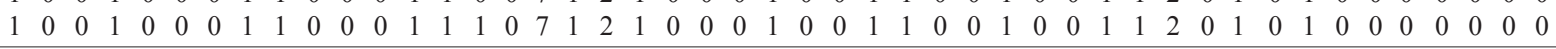

Each asterisk (*) refers to a species with the same coding that was omitted to simplify the analyses. 
Table II. Characters used in the phylogenetic analyses with comments in brackets.

Characters of the Male Genitalia and $8^{\text {th }}$ Tergum

1. Base of gnathos at ventral edge of the lateral window: (0) longer than wide (Fig. 4), (1) as long as wide, shaped a bit like an anvil.

2. Size of teeth on gnathos (Figs. 8-13): (0) none, (1) small, (2) medium.

3. Location of teeth on gnathos (Figs. 8-13): (0) none, (1) one in middle, (2) a few on the basal half, (3) along much of the gnathos.

4. Single flattened ridge on gnathos (Fig. 13): (0) absent, (1) present.

5. Two (or more) rows of small teeth on gnathos: (0) absent, (1) present (Fig. 10). [The flattened outer surface of the gnathos sometimes forms a groove. The grooved condition appears to be an artifact of drying because it may or may not occur in individuals of the same species. The two rows of teeth, when present, are on the outer edges of the flattened surface.]

6. Tip of gnathos: (0) blunt, sometimes with a thick short hook, (1) apiculate, $0.75-1.35 \mathrm{~mm}$ long (Fig. 11), (2) more narrowly apiculate, relatively long, (3) inner and outer surfaces vertically flattened, (4) horizontally flattened and bifurcate.

7. Gnathos thickened on the basal third of the arm: (0) absent, (1) present.

8. Medial anterior edge of dorsal tegumen (Figs. 6-7): (0) approximately dorsal of apex of lateral window, (1) well posterior of apex of lateral window.

9. Labides in lateral aspect (Figs. 6-7): (0) width considerably less than height, (1) width and height similar, (2) width considerably greater than height, (3) rectangular.

10. Ridge on internal tegumen from the "notch" between the labides to the apex of the lateral window: (0) present, (1) absent or vestigial.

11. Labides in dorsal aspect: (0) without posterior processes (Figs. 3-4), (1) with two lateral posterior processes (figure 6 in Field, 1967a), (2) with one small median posterior process.

12. Posterior ventro-lateral edge of vinculum-tegumen: (0) without a process that has teeth on it, (1) with a process with teeth on the ventral surface (Fig. 5), (2) with a process with teeth on the medial edge, (3) with a small process with teeth primarily on the posterior part.

13. Anterior end of vinculum strut in lateral aspect: (0) situated on the ventral half of the genital capsule dorsal of the saccus (Fig. 4), (1) situated about the middle or on the dorsal half of the genital capsule, (2) absent, except for a vestigial trace, (3) barely dorsal of the saccus (Fig. 3).

14. Anterior base of valvae in ventral aspect: (0) separate (figures 10-11 in Robbins \& Duarte, 2005), (1) fused (Fig. 5).

15. Brush organs: (0) absent, (1) present, anterior base in lateral aspect on dorsal half of genital capsule, (2) present, anterior base in lateral aspect on ventral half of genital capsule (Figs. 3-4).

16. Anterior vinculum with sclerotized processes that abut the brush organs (when present): (0) absent, (1) present.

17. Posterior edge of male $8^{\text {th }}$ tergum: (0) straight, (1) convex outward, (2) $8^{\text {th }}$ tergum twisted, (3) slightly concave, (4) small triangular medial incision, (5) two lateral posterior pointing processes, (6) incised, figures 20-21 in Field (1967a), (7) deeply incised, figures 1-12 in Field (1967b).

18. Ductus ejaculatorius enters penis: (0) dorsally, (1) laterally (left side), (2) ventrally (figures 10-11 in Robbins \& Duarte, 2005).

19. Posterior tip of valva: (0) with setae (Fig. 5), (1) flat without setae, (2) without setae, but not flattened.

20. "Parallel" ridges on the internal tegumen near the base of the gnathos (Figs. 14-15): (0) absent, (1) present.

21. Anterior pointing teeth on distal valvae (0) absent, (1) present.

22. Triangular downturned process on left penis tip: (0) absent, (1) present (figures 1-19 in Field, 1967a).

Characters of the Female Genitalia and $8^{\text {th }}$ Tergum

23. Female $8^{\text {th }}$ tergum: $(0)$ without anterior lateral processes (Figs. 16-18, 20-23), (1) with anterior lateral processes (Fig. 19).

24. Lateral edge of $8^{\text {th }}$ tergum: (0) simply sclerotized or not sclerotized (Figs.22- 23), (1) strongly sclerotized and curved (Figs. 16-21).

25. Sclerite in the membrane connecting the anales papiles to the $8^{\text {th }}$ tergum: (0) absent, (1) long, (2) oval (Fig. 19). [A sclerite on this membrane was first reported in Thereus Hübner (Robbins, 1991, 2000)].

26. Length of corpus bursae: (0) $>2 \mathrm{~mm}$ (Fig. 38), (1) $<2 \mathrm{~mm}$ (Fig. 39). [Despite the membranous walls of the corpus bursae, we had no difficulty scoring this character].

27. Signa (Figs. 24-37): (0) boat-shaped, as in Strymon (Robbins \& Nicolay, 2002), (1) fan-shaped, (2) absent to vestigial (of varying shapes), (4) oval to elliptical.

28. Fan-shaped signa: (0) posteriorly tapered or constricted (Figs. 32, 34, 36), (1) posteriorly "U" or "V" shaped.

29. Fan-shaped signa: (0) as wide as long or a bit wider, (1) about twice as long as wide (Fig 30).

30. Spine of signa: (0) present, anterior pointing spine separate from rays when present, (1) absent, (2)"vestigial", anterior spine not separate from central ray.

31. Anterior of signa (Figs. 24-37): (0) with less than 15 major rays protruding beyond the signa, (1) with more than 15 major rays protruding beyond the signa, (2) with a sclerotized circle containing rays.

32. Posterior end of ventral ductus bursae: (0) membranous or lightly sclerotized, (1) strongly sclerotized (Fig. 38).

33. Medial posterior pointing process on ventral, posterior edge of ductus bursae (0) absent, (1) present (Fig. 38).

34. Lamella antevaginalis: (0) membranous or lightly sclerotized, (1) two lightly sclerotized plates (figures 22-34 in Field, 1967a, figures 13-23 in Field, 1967b).

35. Posterior pointing spines on the posterior edge of lamella postvaginalis: (0) absent (Figs 38-39), (1) present (figures 22-34 in Field, 1967a, figures 14-22 in Field, 1967b).

36. Anterior end of ductus bursae: (0) twisted or looped, sclerotized (figures 18-26 in Robbins \& Nicolay, 2002), (1) relatively straight, sclerotized (Figs. 3839), (2) twisted or looped, lightly sclerotized (figures 22-34 in Field, 1967a, figures 13-23 in Field, 1967b).

37. Androconia: (0) absent, (1) present.

Characters of the Wings and Head

38. Orange-red spot distal of the postmedian line in hindwing cell $\mathrm{Cu}_{2}-2 \mathrm{~A}$ : (0) absent, (1) present (Figs. 56-59).

39. Dark brown patch at base of ventral hindwing: (0) lacking, (1) in males only (Figs. 40-43), (2) similar in males and females (Figs. 46-47).

40. Regularly-spaced piliform scales on ventral hindwing vein 2A: (0) absent, (1) present (figure 9 in Robbins \& Duarte, 2005).

41. Regularly-spaced piliform scales on ventral hindwing vein 3A: (0) absent, (1) present.

42. Dorsal surface of wings in male with: (0) without white bands, (1) with white bands, (2) with translucent (hyaline) white bands (Fig. 40).

43. Male dorsal wings (0) no evident copper/orange scales, sometimes a slight orange sheen, (1) copper/orange scales evident (Fig. 52).

44. Orange-red piliform scales on male frons: (0) absent, (1) present.

45. Male dorsal wings with a semi-circle of chalk-blue scales at the inner margin: (0) absent, (1) present (figures of $T$. cleon—a misidentification-and $T$. mathewi in D'Abrera, 1995:1234-1235).

46. Ventral hindwing dark band: (0) none, (1) basal of postmedian line, males only, (2) basal of postmedian line, both sexes, (3) mostly distal of postmedian line, males only (Figs. 42-43, but this character is geographically variable in this species), (4) mostly distal of postmedian line, both sexes (Figs. 46-47). 47. Ventral forewing dark postmedian band: (0) neither sex, (1) only in males (Figs. 40-43), (2) in both sexes (Figs. 46-47). 
Included Species. Ziegleria hesperitis (Butler \& H. Druce) (Figs. 54-55), Z. hoffmani K. Johnson, Z. ceromia (Hewitson), and Z. hernandezi (K. Johnson \& Kroenlein)?? (identification of this name is yet provisional).

Distribution and Habitat. Ziegleria occurs from Mexico to southern Brazil. Ziegleria hesperitis is probably one of the ten most common eumaeine species, occurring in habitats ranging from highly disturbed open areas to the understory of uncut wet forest. Alternately, Z. hernandezi (xeric areas in the northern part of South America) is known from just a few museum specimens.

Remarks. Wing pattern sexual dimorphism is slight (Figs. 54-55), and the male dorsal wing surface may have copper (e.g., Central American individuals of Z ceromia) or blue (e.g., Z. hoffmani) scales.

\section{Kisutam K. Johnson \& Kroenlein, 1993, Revalidated Status}

Diagnosis. We distinguish Kisutam from the remainder of the Calycopidina by base of the male genitalia gnathos about as long as wide, shaped a bit like an anvil (State 1 of Character 1), anterior edge of the dorsal median tegumen well posterior of apex of lateral window (Fig. 7, State 1 of Character 8), width of labides in lateral aspect far greater than height (Fig. 7, State 2 of Character 9), brush organs absent (State 0 of Character 15), and male 8th tergum twisted and asymmetrical (State 2 of Character 17). Shape of the labides and the twisted $8^{\text {th }}$ tergum are unique synapomorphies for Kisutam, but the others are shared with various species of Calycopis and Electrostrymon (Fig. 60).

Nomenclature. The type species of Kisutam K. Johnson \& Kroenlein is Thecla syllis Godman \& Salvin, 1887.

Taxomony. Kisutam was treated as a junior synonym of Ziegleria in Robbins (2004b).

Included Species. Kisutam micandriana (K. Johnson) new combination, $K$. syllis (Godman \& Salvin) new combination, and at least one undescribed montane species.

Distribution and Habitat. Kisutam occurs from Mexico to southern Brazil. Kisutam syllis is one of the most common eumaeine species and is especially abundant in wet forest around decaying fruit on the forest floor. Alternately, $Z$. micandriana (montane forest from Mexico to Nicaragua) is known from just a few museum specimens.

Remarks. As noted, the systematic position of Kisutam is somewhat tenuous because its genitalia are highly apomorphic (superficially similar to those of Calycopis). The genitalia of K. syllis are markedly asymmetrical.

\section{Calycopis Scudder, 1876}

Diagnosis. We distinguish Calycopis from the remainder of the Calycopidina by anterior end of the ductus bursae twisted and lightly sclerotized (State 2 of Character 34, figures 22-34 in Field 1967a; figures 13-23 in Field, 1967b; figures $12-13$ in Robbins \& Duarte 2005) and by an orangered spot distal of the postmedian line in hindwing cell $\mathrm{Cu}_{2}-2 \mathrm{~A}$ (Figs. 56-59, State 1 of Character 38, figures 2, 4, 6, 8 in Robbins \& Duarte 2005).

Nomenclature. The type species of Calycopis is Rusticus armatus poeas Hübner, 1811, a subjective synonym of $C$. cecrops (Fabricius, 1793). The type species of each of the following genera possesses an orange-red spot distal of the postmedian line in hindwing cell $\mathrm{Cu}_{2}-2 \mathrm{~A}$ (Character 38 ), anterior end of the ductus bursae twisted and lightly sclerotized (Character 34), and piliform setae along ventral hindwing vein 2A (Character 38, cerata and tamos are exceptions): Calystryma Field (type species Calystryma blora Field), Femniterga K. Johnson (type species Femniterga notacastanea K. Johnson), Tergissima K. Johnson (type species Tergissima mosconiensis K. Johnson), Cyanodivida K. Johnson (type species Cyanodivida fornoi K. Johnson), Argentostriatus K. Johnson (type species Thecla tamos Godman \& Salvin), Gigantofalca K. Johnson (type species Gigantofalca stacya K. Johnson), Kroenleina K. Johnson (type species Kroenleina panornata K. Johnson), Serratoterga K. Johnson (type species Serratoterga larsoni K. Johnson), Serratofalca K. Johnson (type species Thecla cerata Hewitson), Klaufera K. Johnson (type species Thecla pisis Godman \& Salvin), Distissima K. Johnson (type species Distissima spenceri K. Johnson), Terminospinissima K. Johnson (type species Terminospinissima serratissima K. Johnson), Furcovalva K. Johnson (type species Furcovalva extensa K. Johnson), Morphissima K. Johnson (type species Morphissima scalpera K. Johnson), Antrissima K. Johnson (type species Antrissima varicolor K. Johnson), Reversustus K. Johnson (type species Thecla puppius Godman \& Salvin), Mercedes K. Johnson (type species Thecla demonassa Hewitson), Fieldia K. Johnson (type species Fieldia yungas K. Johnson, a homonym), and Profieldia K. Johnson (a replacement name, type species Fieldia yungas K. Johnson).

Taxonomy. The generic names proposed by K. Johnson and co-authors (Johnson 1988, 1990, 1991, 1993b; K. Johnson et al. 1988; K. Johnson \& Sourakov 1993) are not monophyletic in the phylogenetic results except for monotypic genera, such as Serratofalca. For example, K. Johnson's concept of Tergissima included T. mosconiensis K. Johnson, a species name currently placed in Calycopis, and $T$. shargeli $\mathrm{K}$. Johnson, a species name currently placed in Electrostrymon (Robbins 2004b). The monophyletic Calycopis calus lineage (Node D in Fig. 61) contains species that K. Johnson placed in Argentostriatus and Femniterga, even though the type species of Argentostriatus and Femniterga do not belong to this lineage (Robbins 2004b). The type species of Serratoterga 
and the type species of Klaufera are subjective synonyms of the same species (Robbins 2004b). Similarly, the type species of Femniterga and Tergissima are subjective synonyms of the same species (Robbins 2004b).

Even though the phylogenetic results are discordant with the classifications proposed by K. Johnson and co-authors, there are good reasons for splitting Calycopis into smaller genera. The early work of Field $(1967 \mathrm{a}, \mathrm{b})$ used smaller generic concepts. The sister of Calycopis (Fig. 60) is a lineage of nine genera, and a number of monophyletic groups within Calycopis are recognized in the phylogenetic results (Fig. 60) — some with high bootstrap support—-that could be recognized generically.

However, there are also good reasons for not dividing Calycopis into smaller genera. First, the generic placement of many poorly documented Calycopis species is straightforward because the orange-red spot distal of the postmedian line in hindwing cell $\mathrm{Cu}_{2}-2 \mathrm{~A}$ (Character 38) is conspicuous and easily scored. Alternately, generic placement of poorly documented species would be uncertain with smaller genera because many synapomorphies for lineages within Calycopis are not conspicuous and easily scored. For example, the microscopic ridges inside the labides (Character 20, Figs. 14-15) that characterize the "Calystryma lineage" (Node E in Fig. 61), had not been previously noted. Second, along the same line, adults are immediately recognizable in the field as Calycopis by the ventral hindwing orange-red cubital spot abutting the postmedian line (Fig. 56, Character 38). Alternately, for example, the ventral wing pattern of C. cerata would incorrectly place it in the "Calystryma lineage" (Node $\mathrm{E}$ in Fig. 61). Third, adult behavior is relatively homogenous throughout Calycopis, with individuals most frequently flying near the ground in forest understory in the afternoon, especially at the end of the dry season. Alternately, we cannot distinguish the behavior of many Calycopis adults in different lineages. For example, most members of the "Calystryma lineage" (Node E in Fig. 61) inhabit the understory of wet lowland forest, but species in other lineages also fly in the same habitats. Fourth, if Calycopis were to be divided into three or more genera, the generic placement of Calycopis caesaries and C. sullivani/C. cicero (an identically coded species pair) would be unresolved (Fig. 61). Fifth, the proposed classification is consistent with the only generic classification of the entire Eumaeini (Robbins 2004b). These reasons are the basis for the Calycopis classification in this paper.

Included Species. Calycopis tamos (Godman \& Salvin) (Figs. 56-57), C. matho (Godman \& Salvin)?, C. clarina (Hewitson), C. $\cos$ (H. H. Druce)?, C. atnius (HerrichSchäffer), C. mimas (Godman \& Salvin)?, C. petaurister (H. H. Druce)?, C. calor (H. H. Druce), C. johnsoni (Salazar)?, C. demonassa (Hewitson), C. buphonia (Hewitson), C. calus (Godart), C. wolfi (K. Johnson), C. caesaries (H. H. Druce), C. sullivani Robbins \& Duarte, C. cicero Robbins \& Duarte, C. ledaea (Hewitson)?? (this provisional generic placement is based upon one old, poor male genitalic dissection), C. cerata
(Hewitson), C. cecrops (Fabricius), C. isobeon (Butler \& H. Druce), C. bactra (Hewitson), C. lerbela Field, C. caulonia (Hewitson), C. nicolayi Field, C. bellera (Hewitson), C. xeneta (Hewitson) (Figs. 58-59), C. centoripa (Hewitson), $C$. thama (Hewitson), C. torqueor (H. H. Druce)?, C. vibulena (Hewitson)?, C. origo (Godman \& Salvin), C. drusilla Field?, C. vitruvia (Hewitson), C. partunda (Hewitson)?, C. indigo (H. H. Druce)?, C. anfracta (H. H. Druce)?, C. anastasia Field?, C. fractunda Field?, C. anthora (Hewitson)?, C. spadectis (K. Johnson \& Kroenlein)?, C. malta (Schaus), C. gentilla (Schaus), C. trebula (Hewitson), C. puppius (Godman \& Salvin)?, C. meleager (H. H. Druce), C. pisis (Godman \& Salvin), C. talama (Schaus)?, C. tifla Field?, C. janeirica (C. Felder)?, C. vidulus (H. H. Druce), C. cyanus (Draudt)?? (recent evidence suggests that this name represents an elevational ecotype of C. vidulus), C. orcillula (Strand), C. mirna Robbins \& Duarte, C. orcilla (Hewitson)?, C. blora Field?, C. naka Field?, C. barza Field?, C. gizela (Hewitson)?, C. suda (Draudt)?, C. boliviensis (K. Johnson)?, C. cinniana (Hewitson)?, C. plumans (H. H. Druce)?, C. hosmeri (A.G. Weeks)?, C. vesulus (Stoll)??, and C. cissusa (Hewitson)?

Distribution and Habitat. Calycopis occurs in dry and wet lowland and montane forest from the United States to southern Brazil and central Argentina. Some species are abundant in disturbed areas, and some are similarly common in the understory of uncut wet lowland forest, especially at the end of the dry season.

Remarks. Calycopis is the largest Neotropical eumaeine genus (one species is Nearctic) with 64 described and an undetermined number of undescribed species, but the orangered spot distal of the postmedian line in hindwing cell $\mathrm{Cu}_{2}-2 \mathrm{~A}$ (State 1 of Character 38, Figs. 56-59) allows members of this genus to be immediately recognized with a few exceptions. In two Calycopis species (bellera Hewitson and xeneta Hewitson), the "orange-red" spot is dark brown in males (Fig. 58). On rare occasions, the number of orange-red scales is greatly reduced (Fig. 59), but orange-red scales are always present. In Camissecla camissa, some individuals have orange-red scales, which are also present in some species of Iaspis Kaye (not a member of the Calycopidina).

New conspicuous synapomorphies within Calycopis (proposed by Robbins \& Duarte 2005 or in this paper) include regularly spaced piliform setae on ventral hindwing vein 2A (figure 9 in Robbins \& Duarte 2005, Node C in Fig. 61, Character 40, secondarily "lost" in C. cerata), regularly spaced piliform setae on ventral hindwing vein $3 \mathrm{~A}$ (Node D in Fig. 61, Character 41), ductus ejaculatorius enters the penis ventrally (figures 10-11 in Robbins \& Duarte 2005, State 2 of Character 17), and ridges on the inside surface of the labides (Fig. 15, Node E in Fig. 61, Character 20).

The systematic placement of $C$. cerata is provisional and is the major unresolved aspect of Calycopis "higher" phylogeny. This species shares a ventral wing pattern with the descendents of Node E (Fig. 61), a dorsal wing pattern (muted blue color) with Calycopis caesaries and C. sullivani, 
and genitalic structures with the descendents of Node F and with Kisutam. Alternately, it is the only Calycopis species with a row of small teeth on the male genitalia gnathos (Characters 2 and 3) and the only Calycopis to have "lost" (according to the phylogenetic results, Fig. 60) regularly spaced piliform setae on hindwing vein 2A (Character 40). Despite the systematic placement of $C$. cerata in the middle of Calycopis (Figs. 60-61), a viable alternate hypothesis is that $C$. cerata belongs to Kisutam. If so, the generic name Serratofalca would have priority over Kisutam.

As noted, Calycopis species level taxonomy is poorly resolved, but the ease of rearing immatures (e.g., Duarte et al. 2005; Duarte \& Robbins 2009) has the potential for substantively improving this situation by allowing males and females to be associated and by providing morphological characters of the immature stages.

\section{Calycopidina Comparative Morphology}

Male Genitalia Lateral Window. Eliot (1973) used the term "lateral window" to describe the lightly sclerotized triangle of the tegumen dorsal of the area where the gnathos attach (Figs. 6-7). No function has been attributed to the lateral window, but when the gnathos of a dissected specimen are moved, the lightly sclerotized lateral windows bend.

The apex of the lateral window is situated next to the anterior edge of the vinculum in some Calycopidina species (Figs. 7, State 1 of Character 8), a trait that evolved once in Calycopis, once in Kisutam, and once in Electrostrymon according to the phylogenetic results (Figs. 60-61). Possible functions for this morphology are unknown, but dissected specimens bend slightly between the apex of the lateral window and the anterior edge of the vinculum-tegumen. It is possible that the genitalia "flex" at this point during copulation.

Male Genitalia Labides. The eumaeine labides is modified in some Calycopis, Kisutam, and Electrostrymon, so that they are as wide (or wider) as high in lateral aspect with a variety of posterior pointing processes (Character 9). These modifications in Calycopis were originally illustrated by Field (1967a, b). Some Kisutam, such as K. syllis (Fig. 7 ), have posteriorly produced labides that are twisted and asymmetrical while some Electrostrymon, such as E. guzanta, have wide, almost rectangular, labides in lateral aspect. Analogous modifications of the labides are unreported in other Eumaeini except for Erora Scudder ( $c f$. figures 4, 8 in Field 1941), which does not belong to the Calycopidina.

Signa of the Corpus Bursae. Signa are sclerotized structures that occur in the wall of the corpus bursae and are structurally variable among the Lepidoptera (Klots 1970). Signa presumably function by helping to tear apart spermatophores (Hinton 1964; Cordero 2005; Galicia et al. 2008), but it is unclear how the exact structure (other than absence) is related to function. In any case, the signa that occur in the Calycopidina are complex structures that are highly variable interspecifically (Figs. 24-35).
Field (1967a) illustrated the signa in Calycopis and described them as "platelike ... each ornamented with a centrally placed, rose-thorn shaped spine and with anterior margin deeply dentate." Johnson and co-authors (K. Johnson 1988, 1990, 1991, 1993a,b; K. Johnson et al. 1988; K. Johnson \& Kroenlein 1993a,b, 1997; K. Johnson \& Sourakov 1993; Austin \& K. Johnson 1997; Canals \& K. Johnson 2000) rarely illustrated or described the signa, and did so cursorily when they did. Because the signa in many Calycopidina resemble a fan, they were referred to as "fan-like" (Robbins 2004a; Robbins \& Duarte 2004).

The "deeply dentate" anterior margin (sensu Field, $1967 \mathrm{a}, \mathrm{b}$ ) of the fan-shaped signa are sclerotized "rays" on the inside wall of the corpus bursae (Fig. 37). The rays may have smaller rays. In some Calycopidina, the number of rays is less than 15, but in others (depending upon which of the smaller rays are counted) there are "many". In addition, length of the rays may be relatively uniform or highly variable. The central spine, if present, is hollow with an opening on the wall of the corpus bursae (Fig. 36). On the external surface, the signa may be constricted at the base (Figs. 32, 34, 36). In Camissecla, the signa is twice as long as wide (Fig. 30). We code this variation in Characters 27-31.

Female $8^{\text {th }}$ Tergum. The posterior lateral edge of the female $8^{\text {th }}$ tergum is strongly sclerotized and curved inwards in all species of Calycopidina except for Ziegleria and a few species of Electrostrymon (Figs. 16-23, Character 23). A sclerotized lateral edge of the female $8^{\text {th }}$ tergum occurs otherwise only in some Strymon, where the sclerotization is not curved (Fig. 22). Although shape of the male $8^{\text {th }}$ tergum has been widely illustrated and used as a taxonomic character in genera belonging to the Calycopidina (e.g., Field 1967a,b; K. Johnson 1988, 1990, 1995), the sclerotized lateral edge of the female tergum was only recently proposed (Robbins 2004a; Robbins \& Duarte 2004).

Androconia and Brush Organs. Presumed scent producing structures occur in males of more than $95 \%$ of eumaeine species, are varied in structure, and may occur on the wings or in the abdomen (Robbins 2004a). An estimated $80 \%$ of the species have scent pads or scent patches on some part of the male wings (see Robbins 1991 for terminology), and about half have brush organs (terminology from Eliot 1973), which are abdominal brushes composed of setae with a chamberpresumably containing a scent cell-at the anterior end of each seta (Robbins 1991). The Calycopidina are notable in that no species has androconia, but virtually all have brush organs on the dorsal surface of the vinculum/tegumen (Figs. $2-4$, States 1 and 2 of Character 15). In some cases in the Calycopidina and Strymon, the posterior ends of the brush organs are medially "fused" (Figs. 1-2), a trait that is unusual in the Eumaeini, but this variation is difficult to code because the "separateness" of the posterior ends of the brush organs varies continuously within the Calycopidina.

Sexual Dimorphism and Wings with Alternating Dark and Light Bands. Difficulty in associating the sexes of 
species with sexually dimorphic wing patterns is a relatively widespread problem in the Calycopidina. Many male-female pairings have been proposed (Robbins 2004b, Figs. 40-59) on the basis of similarity in habitat and distribution, rearing of immatures, and copulating pairs. However, the females of many other Calycopidina males are yet unknown or unrecognized.

Hyaline wing spots among butterflies are characteristic of the Hesperiidae and some Nymphalidae, but they also occur in male L. genius and L. japola (Fig. 40, State 2 of Character 42). These spots in Lamprospilus contain a reduced number of white scales and are translucent. The females of these species lack the hyaline wing spots (Fig. 41) and were not associated with the males (e.g., Lathy 1932; D'Abrera 1995) until recently (Robbins 2004b).

Both sexes of a number of Calycopidina - in contrast to the sexually dimorphic species-have similar conspicuous alternating vertical light and dark bands on the ventral wings, of which Arzecla arza is representative (Figs. 46-47). According to the phylogenetic results, this wing pattern evolved once in Arzecla (Node B in Fig. 61) and, depending upon character interpretation, once in the ancestor of $R$. ecbatana.

\section{DISCUSSION}

Calycopidina. Subtribe Calycopidina was monophyletic in all analyses, whether using equal or implied weights (Figs. 60-61). With equal weights, it had a bootstrap value of 71 . Monophyly of the Calycopidina is also supported in analyses of molecular sequences of exemplars from throughout the Eumaeini with bootstrap values of 99 or 100 in Bayesian, likelihood, and maximum parsimony analyses (Quental et $a l$. in prep.). K. Johnson \& Kroenlein (1993b) proposed the nomenclaturally unavailable "infratribe" names Angulopina and Calycopina, but they each contain generic names that belong (e.g., Electrostrymon, Calycopis, respectively) and do not belong (e.g., Nicolaea K. Johnson, Iaspis Kaye, respectively) to the Calycopidina (Johnson \& Kroenlein, 1993b). Lamprospilus was not placed in either "infratribe" (K. Johnson \& Kroenlein 1993b).

A major synapomorphy of the Calycopidina is the inwardly curved, strongly sclerotized lateral edge of the female $8^{\text {th }}$ tergum (Figs. 16-23). This trait does not occur elsewhere in the Eumaeini. In Arzecla nubilum, a muscle connects this sclerotization to the anterior end of the apophyses posteriores (Robbins, unpubl.). Since the apophyses posteriores are caudal extensions of the papillae anales (the female ovipositor, Klots 1970), constriction of this muscle presumably affects oviposition. If this hypothesis were correct, it would be interesting to see where this muscle attaches in other female eumaeines and in those Ziegleria and Electrostrymon that lack the sclerotization.

Another major synapomorphy of the Calycopidina is the presence of fan-shaped signa, which are characterized in the morphological results (Figs. 24-37). Outside of the Calycopidina, they occur in several genera of the Micandra Section and in Hypostrymon Clench and Marachina Robbins, but preliminary analysis of molecular sequences suggests that
Hypostrymon and Marachina belong to the Micandra Section (Quental et al. in prep.). Fan-shaped signa evolved once in the Calycopidina according to the phylogenetic results (Figs. 60-61) and may have also evolved once in the Micandra Section of the Eumaeini. Within the Calycopidina when fanshaped signa are vestigial or absent, the corpus bursae is less than $2 \mathrm{~mm}$ long. A number of hypotheses have been proposed to explain the evolution of signa (Cordero 2005; Galicia et al. 2008), but the mating systems of Calycopidina have not been investigated so far.

A third major trait of the Calycopidina is the lack of wing scent pads and scent patches, as characterized morphologically in Robbins (1991). Outside of the Calycopidina, the only genera to lack androconia uniformly are Podanotum Torres \& K. Johnson, Contrafacia K. Johnson, Chlorostrymon Clench, and Semonina Robbins. Alternately, most Calycopidina possess abdominal brush organs (Figs. 1-4). The evolution of scent pads and brush organs and their relationship to diversification in the Eumaeini is being examined elsewhere (Quental et al. in prep.).

Detritivory. Very briefly overviewed, there is some evidence for detritivory in all Calycopidina genera except for Rubroserrata (Robbins et al. in prep.). Females of Lamprospilus, Ziegleria, Electrostrymon, and Calycopis have been observed in nature ovipositing on dead leaves and twigs on the ground, and in one case, eggs were found on a dead seedling (Aiello \& Robbins unpubl.). Most females of Lamprospilus, Badecla, Camissecla, Arzecla, Arumecla, Ziegleria, Electrostrymon, and Calycopis oviposit readily on dead leaves in the laboratory while non-Calycopidina females do not (Duarte, Robbins, Aiello unpubl.). Caterpillars of Calycopis have been found repeatedly in the leaf litter (W. Steiner, unpubl., voucher in USNM), and larvae of Lamprospilus, Kisutam, and Electrostrymon have been discovered eating fallen flower corollas and fruits on the forest floor (Robbins \& Aiello 1982; Feinstein et al. 2007; Robbins unpubl.). Although many butterflies, including Lycaenidae, can be reared on an artificial diet to which dried, ground leaves of the foodplant are added (Morton 1981; Mark 1993, 1995), caterpillars of Lamprospilus, Badecla, Camissecla, Arzecla, Arumecla, Ziegleria, Electrostrymon, and Calycopis readily eat and complete development on an agar-based artificial diet without the addition of plant material (Duarte et al. 2005; Duarte \& Robbins 2009; Aiello $\&$ Robbins in prep.; Duarte unpubl.). Larvae of Calycopidina can eat a wide variety of fresh plant leaves (S. Johnson 1985) and are sometimes found eating live plants (Robbins et al. unpubl.; Duarte unpubl.), for which reasons we presume that detritivory in the Calycopidina is facultative, at least in some cases. Detritivores may obtain most of their nutrition from detritus or from the micro-organisms living on detritus (e.g., Findlay \& Tenore 1982; Hohn \& Wagner 2002), but it is yet uncertain which is more important for the Calycopidina.

Generic Classification. The proposed generic classification of the Calycopidina is a "work in progress" for two reasons. First, relations among the Calycopidina genera 
are not well-resolved with low bootstrap support for some lineages because we were unable to code a sufficient number of adult morphological characters to obtain better results. We are skeptical that adult morphology will provide a substantial number of new phylogenetically informative characters, for which reason we have begun working with the morphology of the immatures (Duarte et al. 2005; Duarte \& Robbins 2009) and are collaborating on sequencing genes among Calycopidina species (Quental et al. in prep.). Second, about a quarter of Calycopidina species are known from one sex, and another quarter are undescribed (Robbins 2004b). Incorporating these species into the classification will undoubtedly modify some generic characterizations.

Despite the provisional status of the proposed generic classification of the Calycopidina, all recognized genera were monophyletic in the most parsimonious trees (Fig. 61) while most previous characterizations of non-monotypic genera were not. All genera were monophyletic over a wide range of implied weight fits. Further, phylogenetic relations among the genera (as shown in Fig. 60) were resolved and identical in the set of 594 trees that were most parsimonious with equal weights and with implied weights ranging from $\mathrm{k}=10$ to 1,000. For this reason, we consider it to be the best estimate, albeit provisional, of relations among the Calycopidina genera. It is a starting point for documenting the undescribed species in generic revisions and for studying the evolution of detritivory in the Lycaenidae.

Acknowledgements. For allowing us access over the past three decades to collections under their care, we thank the responsible curators at the Coleção Entomológica Pe. Jesus Santiago Moure da Universidade Federal do Paraná, Fundação Instituto Oswaldo Cruz, Museo de Historia Natural de Universidad Nacional Mayor de San Marcos, Museo Ecuadoriano de Ciencias Naturales, Museo del Instituto de Zoología Agrícola, Universidad Nacional Autonoma de Mexico (Facultad de Sciences and Instituto de Biologia), Allyn Museum of Entomology (Florida State Museum), Los Angeles County Museum, Carnegie Museum of Natural History, American Museum of Natural History, Oregon State University, Milwaukee Public Museum, Museum of Comparative Zoology, Muséum National d'Histoire Naturelle, Zoologische Staatssammlung, Staatliches Museum für Naturkunde, Forschungsinstitut und Naturmuseum Senckenberg, Museum für Naturkunde der HumboldtUniversität, Natural History Museum, Nationaal Natuurhistorische Museum ("Naturalis"), and Zoological Museum at the University of Copenhagen. For allowing us to examine specimens in their private collections (some now deposited in museums), we thank Dick Anderson, Keith Brown, Robert Busby, Charles Covell, Jason Hall, Roy Kendall, Mike McInnis, Stan Nicolay, and too many others to list. For discussions on hairstreak systematics, we are grateful to Stan Nicolay, Robert Busby, Jason Hall, Mike McInnis, and Bo Sullivan. For discussions on nomenclature related to this paper, we thank Gerardo Lamas and Jeffrey Glassberg. We are pleased to acknowledge our collaborators on eumaeine molecular systematics, Tiago Quental and Naomi Pierce, and our collaborators on detritivory, Annette Aiello, Amy Berkov, Julie Feinstein, and Warren Steiner. We thank Don Harvey for discussions over many years on detritivory and rearing immatures. We thank Brian Harris for many kinds of technical help. We thank Karie Darrow for the photographic plates in this paper and Vichai Malikul for the expert illustrations. The Willi Hennig Society provided free downloads of TNT software. For discussions on phylogenetic analysis, we are grateful to Sean Brady, Jon Coddington, Robert Kula, Peterson L. Lopes, Wayne Mathis, Cristiano Moreira, Silvio Nihei, and Ted Schultz. For reading and commenting on the paper, we are most grateful to Robert C. Busby, Sônia A. Casari, André V. L. Freitas, Carlos José E. Lamas, Gerardo Lamas, and Carlos Peña. For supporting Duarte during his "sandwich" fellowship to Smithsonian, during which this project began, we are grateful to Coordenação de Aperfeiçoamento de Pessoal de Nível Superior/CAPES (process number BEX0385/01-8). For supporting travel by both Duarte and Robbins and for substantial funds, we thank Fundação de Amparo à Pesquisa do Estado de São Paulo/FAPESP (as part of the project "Systematics, Bionomy, and Evolution of Neotropical Lepidoptera"; process numbers 02/13898-0 and 03/13985-3) and PróReitoria de Pesquisa da Universidade de São Paulo/USP/Projeto 1.

\section{REFERENCES}

Austin, G. T. \& K. Johnson. 1997. Theclinae of Rondônia, Brazil: Gigantorubra and Angulopis, with descriptions of new species (Lepidoptera: Lycaenidae). Insecta Mundi 11: 255-272.

Brown, K. S. Jr. 1992. Borboletas da Serra do Japi: diversidade, hábitats, recursos alimentares e variação temporal, p. 142-187. In: L. P. C. Morellato (ed.). História natural da Serra do Japi: ecologia e preservação de uma área florestal no Sudeste do Brasil. Campinas, Editora da UNICAMP/FAPESP, $321 \mathrm{p}$.

Canals, G. R. \& K. Johnson. 2000. A new species of Angulopis (Lycaenidae, Eumaeini) from relict coastal forest in East-Central Argentina. The Taxonomic Report of the International Lepidoptera Survey 2: 1-5.

Comstock, J. H. 1918. The wings of insects. Ithaca, Comstock Publishing Company, $430 \mathrm{p}$.

Cordero, C. 2005. The evolutionary origin of signa in female Lepidoptera: natural and sexual selection hypotheses. Journal of Theoretical Biology 232: 443-449.

Cottrell, C. B. 1984. Aphytophagy in butterflies: its relationship to myrmecophily. Zoological Journal of the Linnean Society 79: 1-57.

D'Abrera, B. L. 1995. Butterflies of the Neotropical region. Part VII. Lycaenidae. Black Rock, Hill House, 173 p.

Draudt, M. 1919-1920. Theclini F., p. 744-812. In: A. Seitz (ed.). Die GrossSchmetterlinge der Erde, vol. 5. Die amerikanischen Tagfalter. Stuttgart, Alfred Kernen, 88 p.

Duarte, M. \& R. K. Robbins. 2009. Immature Stages of Calycopis bellera (Hewitson) and C. janeirica (Felder) (Lepidoptera, Lycaenidae, Theclinae, Eumaeini): Taxonomic Significance and New Evidence for Detritivory, Zootaxa 2325: 39-61.

Duarte, M.; R. K. Robbins \& O. H. H. Mielke. 2005. Immature stages of Calycopis caulonia (Hewitson, 1877) (Lepidoptera, Lycaenidae, Theclinae, Eumaeini), with notes on rearing detritivorous hairstreaks on artificial diet. Zootaxa 1063: 1-31.

Ehrlich, P. R. \& P. H. Raven. 1965. Butterflies and plants: a study in coevolution. Evolution 18: 586-608.

Eliot, J. N. 1973. The higher classification of the Lycaenidae (Lepidoptera): a tentative arrangement. Bulletin of the British Museum (Natural History) (Entomology) 28: 371-505.

Faynel, C. \& Z. Bálint 2004. Supplementary information on neotropical Eumaeini primary type material and further historical specimens deposited in the Muséum national d'Histoire naturelle, Paris (Lycaenidae, Theclinae). Bulletin de la Société Entomologique de France 109: 263-286.

Feinstein, J.; S. Mori \& A. Berkov. 2007. Saproflorivory: a diverse insect community in fallen flowers of Lecythidaceae in French Guiana. Biotropica 39: 549-554.

Field, W. D. 1941. Notes on Erora laeta (Edwards) and Erora quaderna (Hewitson) (Lepidoptera, Lycaenidae). Annals of the Entomological Society of America 34: 303-316.

Field, W. D. 1967a. Preliminary revision of butterflies of the genus Calycopis Scudder (Lycaenidae: Theclinae). Proceedings of the United States National Museum 119: 1-48.

Field, W. D. 1967b. Butterflies of the new genus Calystryma (Lycaenidae: Theclinae, Strymonini). Proceedings of the United States National Museum 123: 1-31.

Findlay, S. \& K. Tenore. 1982. Nitrogen source for a detritivore: detritus substrate versus associated microbes. Science 218: 371-373.

Galicia, I.; V. Sánchez \& C. Cordero. 2008. On the function of signa, a genital trait of female Lepidoptera. Annals of the Entomological Society of America 101: 786-793.

Gifford, S. M. \& P. A. Opler. 1983. Natural history of seven hairstreaks in 
coastal North Carolina. Journal of the Lepidopterists' Society 37: 97-105.

Goloboff, P. 1999. NONA ver. 2. Tucumán, Published by the author.

Goloboff, P.; J. Farris \& K. Nixon. 2003. T.N.T. Tree analysis using new technology. Program and documentation available from the authors. $<$ www.zmuc.dk/public/phylogeny>. Access 01/04/2009.

Hall, J. P. W. \& D. J. Harvey. 2002. A phylogenetic review of Charis and Calephelis (Lepidoptera: Riodinidae). Annals of the Entomological Society of America 95: 407-421.

Hinton, H. E. 1964. Sperm transfer in insects and the evolution of haemocelic insemination, p. 95-107. In: K. C. Highnam (ed.). Insect Reproduction. London, Symposium of the Royal Entomological Society of London, $120 \mathrm{p}$.

Hohn, F. M. \& D. L. Wagner. 2002. Larval substrates of herminiine noctuids (Lepidoptera): macrodecomposers of temperate leaf litter. Environmental Entomology 29: 207-212.

ICZN. 1999. International Code of Zoological Nomenclature. 4th edition. London, The International Trust for Zoological Nomenclature.

Johnson, K. 1988. Tergissima and Femniterga, new sister genera of Calycopis Scudder and Calystryma Field from the South Central Andes (Lepidoptera: Lycaenidae). Insecta Mundi 2: 28-42.

Johnson, K. 1990. A revision of the South American hairstreak butterfly genera Tergissima and Femniterga (Lycaenidae: Theclinae). Insecta Mundi 3: 195-215.

Johnson, K. 1991. Neotropical hairstreak butterflies: Genera of the "Calycopis/Calystryma Grade" of Eumaeini (Lepidoptera, Lycaenidae, Theclinae) and their diagnostics. Reports of the Museum of Natural History, University of Wisconsin 21: 1-128.

Johnson, K. 1993a. Neotropical hairstreak butterflies: New sister genera of the "Electrostrymon/Angulopis" grade of Eumaeini (Lepidoptera, Lycaenidae, Theclinae). Reports of the Museum of Natural History, University of Wisconsin 32: 1-76.

Johnson, K. 1993b. Hairstreak butterflies of the genus Argentostriatus (Lepidoptera, Lycaenidae, Theclinae). Reports of the Museum of Natural History, University of Wisconsin 36: 1-19.

Johnson, K. 1995. A new species of Gigantofalca from Argentina (Lycaenidae). Journal of the Lepidopterists' Society 49: 31-38.

Johnson, K.; R. C. Eisele \& B. N. MacPherson. 1988. The "hairstreak butterflies" (Lycaenidae, Theclinae) of northwestern Argentina. I. Introduction, Calycopis, Calystryma, Tergissima \& Femniterga. Bulletin of the Allyn Museum 123: 1-49.

Johnson, K. \& K. R. Kroenlein. 1993a. Revision of Angulopis (Lepidoptera, Lycaenidae, Theclinae). Reports of the Museum of Natural History, University of Wisconsin 33: 1-38.

Johnson, K. \& K. R. Kroenlein. 1993b. New genera and species of the "gem butterflies" (Lepidoptera, Lycaenidae, Theclinae). Reports of the Museum of Natural History, University of Wisconsin 34: 1-42.

Johnson, K. \& K. R. Kroenlein. 1997. A new species of Argentostriatus from Colombia (Lycaenidae: Eumaeini). Revista de Theclinae Colombianos 2: $1-7$.

Johnson, K.; J. A. Salazar; J. I. Vargas \& E. R. Henao. 2004. Nuevas especies y subespecies de Rhopalocera para Colombia (Insecta, Lepidoptera: Lycaenidae, Riodinidae, Satyridae). Boletín Científico Museo de Historia Natural Universidad de Caldas 8: $303-316$.

Johnson, K. \& A. Sourakov. 1993. Hairstreak butterflies of the genus Serratofalca (Lepidoptera: Lycaenidae). Tropical Lepidoptera 4: 107-118.

Johnson, S. A. 1985. Culturing a detritivore, Calycopis isobeon (Butler \& Druce). News of the Lepidopterists' Society 3: 41-42.

Klots, A. B. 1970. Lepidoptera, p. 115-130. In: S. L. Tuxen (ed.). Taxonomist's glossary of genitalia in insects. Copenhagen, Munkssgard, $284 \mathrm{p}$.

Lamas, G.; R. G. Robbins \& W. D. Field. 1995. Bibliography of butterflies. An annotated bibliography of the Neotropical butterflies and skippers (Lepidoptera: Papilionoidea and Hesperioidea). In: J. B. Heppner (ed.). Atlas of Neotropical Lepidoptera. vol. 124, Gainesville, Association for Tropical Lepidoptera, $463 \mathrm{p}$.

Lathy, P. I. 1932. The genus Lamprospilus (Lepidoptera). Annals and Magazine of Natural History 9: 180-182.
Mark, H.-G. 1993. Erste Mitteilung über Tagfalter- und Zygänenzuchten mit semisynthetischem Kunstfutter. Nachrichten des Entomologischen Vereins Apollo, N.F., 14: 275-280.

Mark, H.-G. 1995. Tagfalter- und Zygaenenzuchten mit semisynthetischem Kunstfutter, zweite Mitteilung: Lepidoptera, Lycaenidae. Nachrichten des Entomologischen Vereins Apollo, N.F., 16: 263-274.

Morton, R. S. 1981. Rearing butterflies on artificial diet. Journal of Research on the Lepidoptera 18: 221-227.

Murray, D. L. 2001. Systematics of euptychiine butterflies (Nymphalidae: Satyrinae: Euptychiina) based on larval morphology and DNA sequence data and the evolution of life history traits. Ph.D. dissertation, Louisiana State University, Baton Rouge.

Nixon, K. C. 2002. WinClada ver. 1.0000. Ithaca, Published by the author.

Nixon, K. C. \& J. M. Carpenter. 1993. On outgroups. Cladistics 9: 413-426.

Pierce, N. E. 1995. Predatory and parasitic Lepidoptera: carnivores living on plants. Journal of the Lepidopterists' Society 49: 412-453.

Powell, J.; C. Mitter \& B. D. Farrell. 1998. Evolution of larval food preference in Lepidoptera, p. 403-422. In: N. P. Kristensen (ed.). Lepidoptera, Moths and Butterflies, vol. 1: Evolution, Systematics, and Biogeography. In: M. Fischer (ed.). Handbuch der Zoologie. Handbook of Zoology. Band/ Volume IV Arthropoda: Insecta. Berlin, Walter de Gruyter. 491 p.

Robbins, R. K. 1991. Evolution, comparative morphology, and identification of the eumaeine butterfly genus Rekoa Kaye (Lycaenidae: Theclinae). Smithsonian Contributions to Zoology 498: 1-64.

Robbins, R. K. 2000. The New World hairstreak genus Arawacus Kaye (Lepidoptera: Lycaenidae: Theclinae: Eumaeini). Proceedings Entomological Society of Washington, 102: 162-169.

Robbins, R. K. 2004a. Introduction to the checklist of Eumaeini (Lycaenidae), p. xxiv-xxx. In: G. Lamas (ed.). Checklist: Part 4A. Hesperioidea - Papilionoidea. In: J. B. Heppner (ed.). Atlas of Neotropical Lepidoptera. Vol 5A. Gainesville, Association for Tropical Lepidoptera, Scientific Publishers, 439 p.

Robbins, R. K. 2004b. Lycaenidae. Theclinae. Tribe Eumaeini, p. 118-137. In: G. Lamas (ed.). Checklist: Part 4A. Hesperioidea - Papilionoidea. In: J. B. Heppner (ed.). Atlas of Neotropical Lepidoptera. Vol. 5A Gainesville, Association for Tropical Lepidoptera, Scientific Publishers, $439 \mathrm{p}$.

Robbins, R. K. \& A. Aiello. 1982. Foodplant and oviposition records for Panamanian Lycaenidae and Riodinidae. Journal of the Lepidopterists' Society 36: 65-75.

Robbins, R. K. \& M. Duarte. 2004. Descriptions of new butterfly genera. Lycaenidae, Eumaeini, p. 275-282. In: G. Lamas (ed.). Checklist: Part 4A. Hesperioidea - Papilionoidea. In: J. B. Heppner (ed.). Atlas of Neotropical Lepidoptera. Vol 5A. Gainesville, Association for Tropical Lepidoptera, Scientific Publishers, 439p.

Robbins, R. K. \& M. Duarte. 2005. Two phylogenetically significant new Calycopis species (Lycaenidae: Theclinae: Eumaeini). Journal of Research on the Lepidoptera 38: 27-34.

Robbins, R. K. \& P. Henson. 1986. Why Pieris rapae is a better name than Artogeia rapae (Pieridae). Journal of the Lepidopterists' Society 40 : 79-92.

Robbins, R. K.; G. Lamas; O. H. H. Mielke; D. J. Harvey \& M. M. Casagrande. 1996. Taxonomic composition and ecological structure of the species-rich butterfly community at Pakitza, Parque Nacional del Manu, Peru, p. 217-252. In: D.E. Wilson \& A. Sandoval (eds.). Manu: the biodiversity of Southeastern Peru. Washington, DC, Smithsonian Institution Press, 679p.

Robbins, R. K. \& S. S. Nicolay. 2002. An overview of Strymon Hübner (Lycaenidae: Theclinae: Eumaeini). Journal of the Lepidopterists' Society 55: $85-100$.

Snodgrass, R. E. 1935. Principles of insect morphology. New York, McGraw-Hill Book Co., 667 p.

Wagner, D. L.; J. Rota \& T. L. McCabe. 2008. Larva of Abablemma (Noctuidae) with notes on algivory and lichenivory in Macrolepidoptera. Annals of the Entomological Society of America 101: 40-52. 